


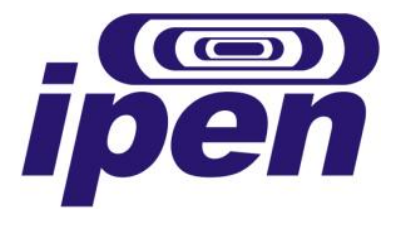

AUTARQUiA ASSOCIADA À UNIVERSIDADE DE SÃO PAULO

\title{
PROPOSTA DE UM QUESTIONÁRIO DESTINADO A AVALIAR A PERCEPÇÃO DE RISCO RELATIVA A UM REPOSITÓRIO DE REJEITOS RADIOATIVOS
}

\author{
KÁTIA SUEMI TANIMOTO
}

Dissertação apresentada como parte dos requisitos para a obtenção do grau de Mestre em Ciências na Área de Tecnologia Nuclear

- Aplicações

Orientador:

Prof. Dr. Goro Hiromoto

São Paulo 


\section{AGRADECIMENTOS}

Aos meus pais Sueli Akiko Sudoh Tanimoto e Carlos Mituo Tanimoto, pela vida, por todo o investimento, amor e fé que depositaram em mim.

À minha vó Yoko Sudoh, pelo carinho, compreensão e confiança.

À minha irmã Karina Harumi Tanimoto, pelo companheirismo em momentos bons e ruins.

Ao meu namorado Gustavo Machado Coelho, pelo amor e respeito.

Ao meu orientador Dr. Goro Hiromoto, pela orientação, paciência e fundamental incentivo durante o transcorrer deste trabalho.

Aos amigos Amanda Bravim, Elaine Wirney, Fernanda Nonato, Rafael Mendes, Ivani Fernandes e Amanda Juliene, pelo companheirismo e apoio.

Ao Instituto de Pesquisas Energéticas e Nucleares (IPEN/CNEN - SP), pela oportunidade de realização do trabalho.

À Comissão Nacional de Energia Nuclear, pelo auxílio financeiro fornecido na forma de bolsa de estudo.

A todos aqueles que contribuíram, direta ou indiretamente, para a realização deste trabalho. 


\title{
PROPOSTA DE UM QUESTIONÁRIO DESTINADO A AVALIAR A PERCEPÇÃO DE RISCO RELATIVA A UM REPOSITÓRIO DE REJEITOS RADIOATIVOS
}

\author{
KÁTIA SUEMI TANIMOTO
}

\section{RESUMO}

Um aspecto fundamental da aceitação pública da energia nuclear é a crença de que os rejeitos radioativos podem ser gerenciados de maneira segura, no intuito de proteger os seres humanos dos possíveis efeitos prejudiciais, tanto nas gerações atuais como nas futuras. Neste sentido, é essencial compreender como as pessoas percebem o risco associado com rejeitos radioativos e quais são os principais fatores que conduzem suas atitudes em relação à eliminação destes. Uma das maneiras para alcançar esse entendimento é através de pesquisas de opinião. Neste estudo, foi proposto um questionário focado na questão da aceitabilidade da energia nuclear e sua associação com a gestão de rejeitos radioativos, cobrindo os seguintes aspectos: atitudes em relação à energia nuclear e aos rejeitos radioativos, credibilidade das instituições e setores responsáveis pela segurança nuclear, identificação dos benefícios percebidos; percepção do risco de determinadas tecnologias e atividades, percepção do risco real, compreensão das reações emocionais e princípio da precaução. Resultados obtidos a partir de uma aplicação piloto do questionário são apresentados e discutidos neste trabalho. 


\title{
PROPOSAL FOR A QUESTIONNAIRE TO ASSESS RISK PERCEPTION CONCERNING A RADIOACTIVE WASTE REPOSITORY
}

\author{
KÁTIA SUEMI TANIMOTO
}

ABSTRACT

One of the key features for public acceptance of nuclear energy is the belief that radioactive waste can be managed safely, in order to protect human beings from its possible harmful effects in present and future generations. In this sense, it is essential to understand how people perceive the risk associated with radioactive waste and which the main factors driving their attitudes toward its disposal are. One of the ways to achieve this understanding is through opinion polls. In this study, a questionnaire focused on the nuclear energy aceitability issue and its association with radioactive waste management was proposed, covering the following aspects: attitudes towards radioactive waste and nuclear power, credibility on institutions and sectors responsible by the nuclear safety, identification of perceived benefits, risk perception of specific technologies and activities, perception of real risk, emotional reaction comprehension and precautionary principle. Results obtained from a pilot questionnaire application are presented and discussed in this paper. 


\section{SUMÁRIO}

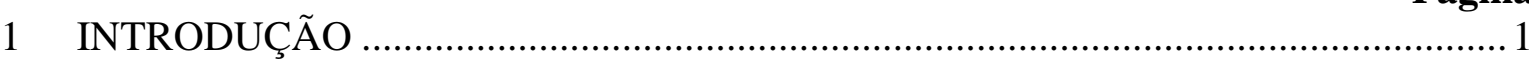

2 OBJETIVOS

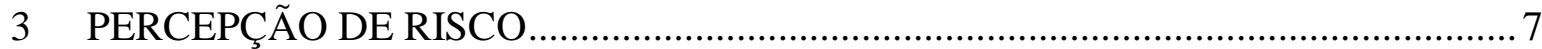

4 METODOLOGIAS DE PESQUISAS DE OPINIÃO.................................................. 14

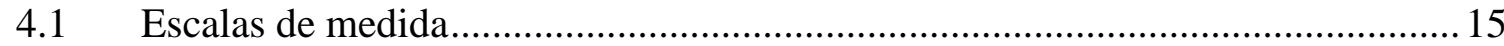

4.1.1 Escalas nominais .......................................................................... 15

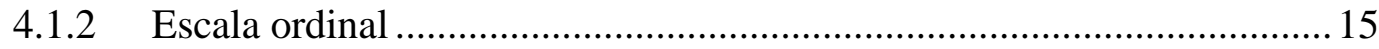

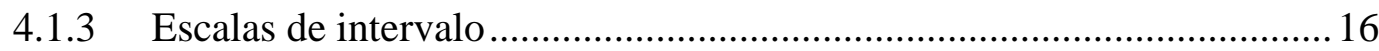

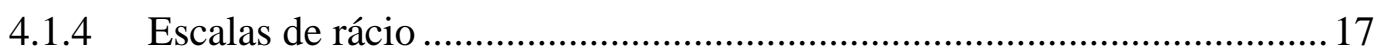

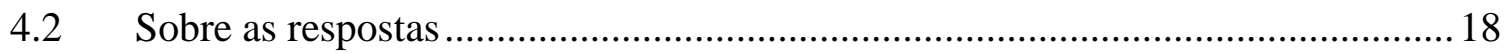

4.2.1 O número de respostas alternativas ......................................................... 18

4.2.2 A ordem dos valores numéricos associados às respostas .......................... 18

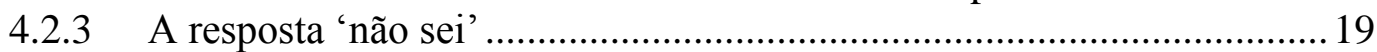

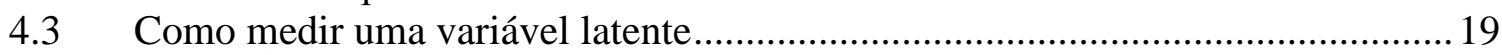

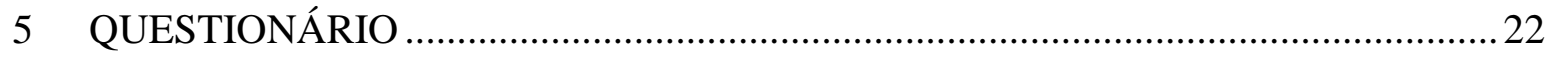

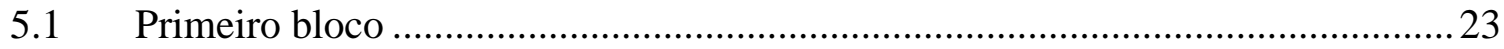

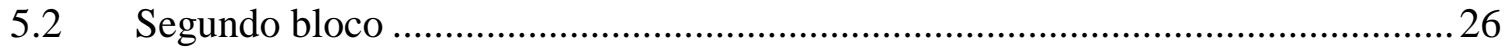

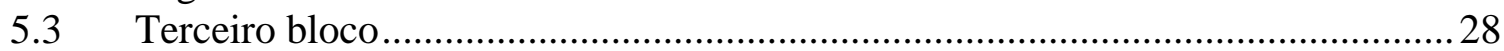

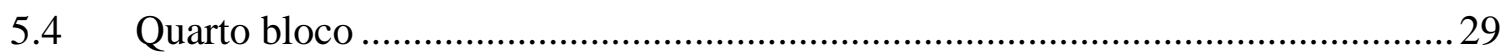

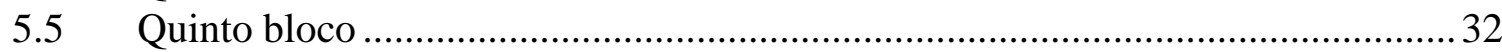

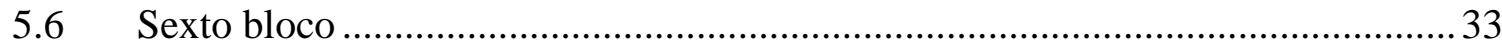

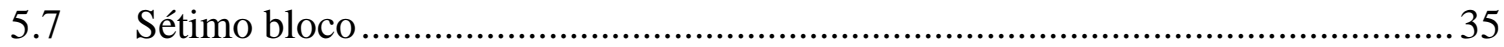

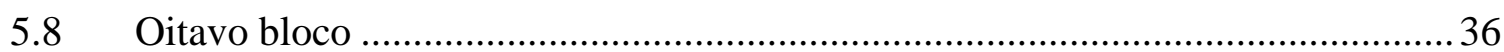

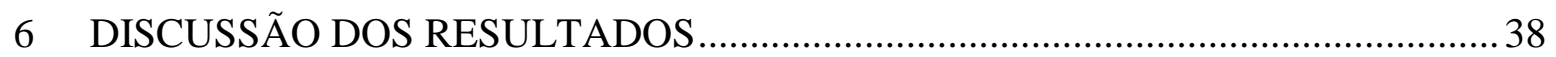

6.1 Das atitudes e aceitabilidade do repositório em seu município ........................................38

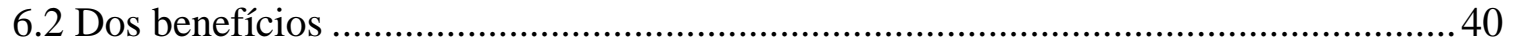

6.3 Da comparação com a percepção de outros riscos ..................................................... 41

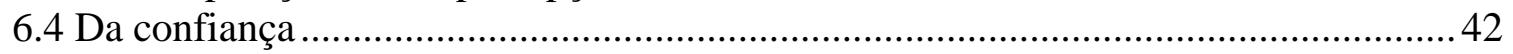

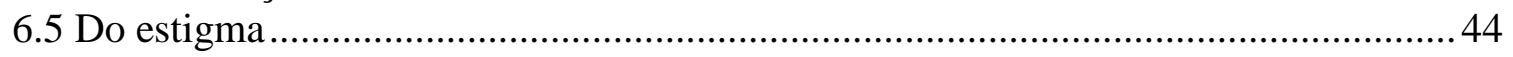

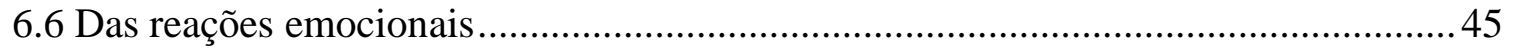

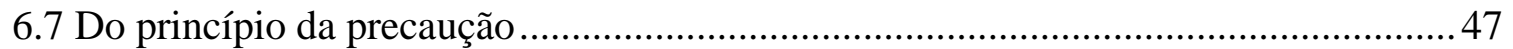

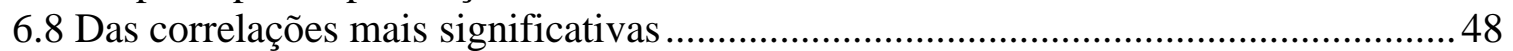

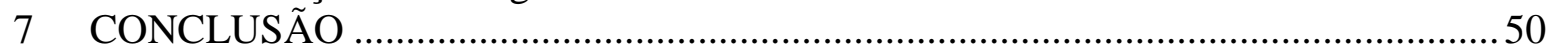

APÊNDICE A - Questionário para estudo de percepção de riscos tecnológicos .................51

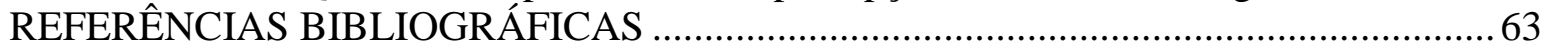




\section{LISTA DE TABELAS}

Tabela 1 Concordância com as alegações de estigma e correlações com atitude

Tabela 2 Correlações entre emoções positivas, emoções negativas e atitude com relação a

um depósito de rejeitos radioativos

Tabela 3 Percentual dos que concordam com as alegações acerca do depósito de rejeitos radioativos e correlação destas com aceitabilidade do depósito 


\section{LISTA DE FIGURAS}

Figura 1 Esquema da matriz energética mundial e da matriz energética brasileira.

\section{1}

Figura 2 A percepção de risco como parte do gerenciamento de riscos .

Figura 3 İndices do sentimento (1 para extremamente negativo, 7 para extremamente positivo) e da aceitabilidade

(1 para totalmente inaceitável, 7 para totalmente aceitável)

Figura 4 Percentual dos entrevistados que demonstraram sentimento negativo e consideraram o depósito de rejeitos radioativos inaceitável..

Figura 5 Percentual dos benefícios do depósito e dos que o consideram inaceitável.....

Figura 6 Índices de risco pessoal e coletivo para vários perigos ..................................42

Figura 7 Percentual dos respondentes que confiam nas organizações e autoridades listadas

Figura 8 Percentual dos entrevistados que confiam nas autoridades governamentais e na Comissão Nacional de Energia Nuclear (CNEN)

Figura 9 Índices de emoções positivas e negativas para depósito de rejeitos radioativos e rejeito radioativo 


\section{INTRODUÇÃO}

O Brasil possui 1768 usinas em operação, que correspondem a uma capacidade instalada de 104816 MW. Destas, 159 são hidrelétricas, 1042 térmicas abastecidas por fontes diversas (gás natural, biomassa, óleo diesel e óleo combustível), 320 Pequenas Centrais Hidrelétricas (PCHs), duas nucleares, 227 centrais geradoras hidrelétricas (pequenas usinas hidrelétricas) e uma solar. (ANEEL, 2008).

A Figura 1 apresenta a matriz energética mundial e a brasileira. Pode-se notar que a energia nuclear responde por $5,8 \%$ da oferta de energia elétrica no mundo e 3,1\% no Brasil.

Matriz energética - 2008

(Oferta interna de energia elétrica)
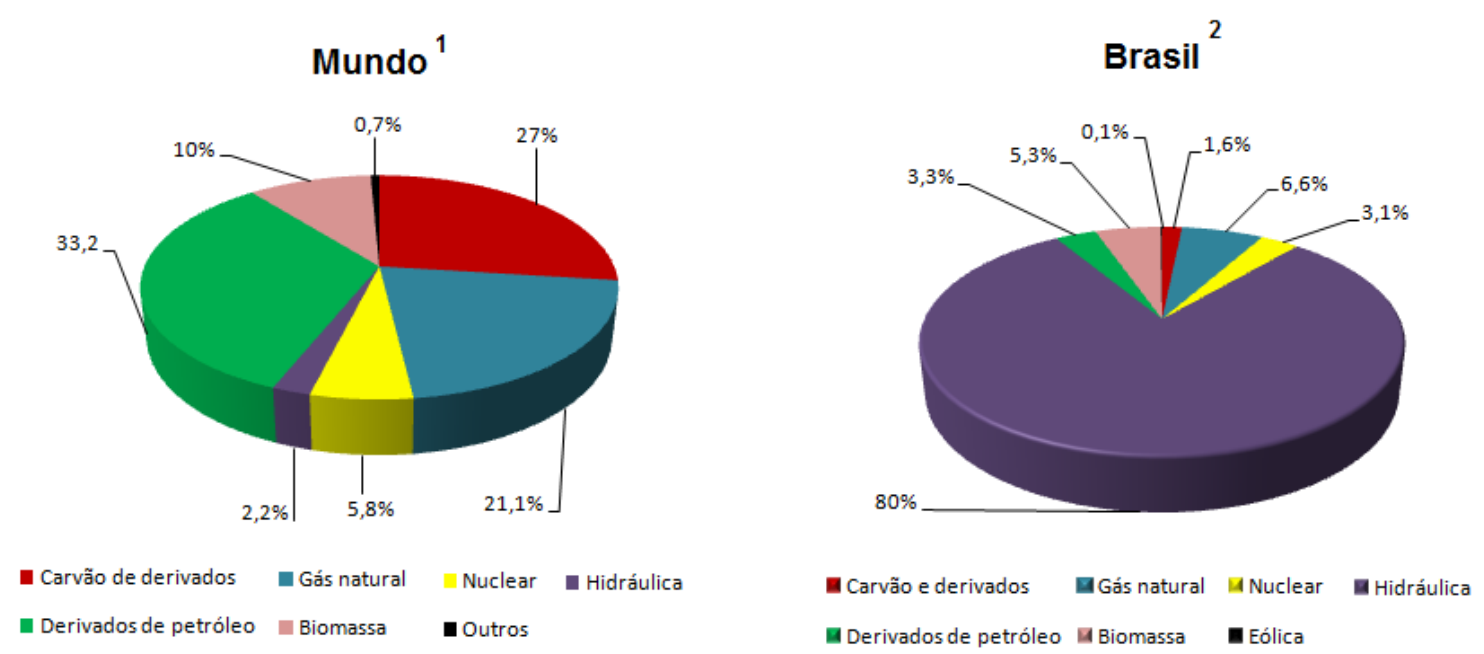

Figura 1 Esquema da matriz energética mundial ${ }^{1}$ e da matriz energética brasileira ${ }^{2}$.

A região de Angra dos Reis é onde se encontra o complexo nuclear brasileiro. O Brasil possui dois reatores em operação, Angra I, com potência de 657 MW e Angra II, com potência de 1350 MW. A operação de Angra III está

\footnotetext{
${ }^{1}$ Fonte: Key World Energy Statistics, International Energy Agency, 2010, p. 6

${ }^{2}$ Fonte: Balanço Energético Nacional, Ministério de Minas e Energia, 2009, p. 20.
} 
prevista para ter início em 2014. Com isto, a participação da capacidade nuclear instalada no Brasil deve passar de 1,98\% (2007 GW) para 2,5\% (3,357 GW) da capacidade instalada total, considerando que esta última terá um crescimento anual de 4\%, passando de 103 GW (2008) para 130 GW em 2014 (ANEEL, 2008).

A expansão do programa nuclear brasileiro está fortemente associada à solução definitiva para o destino final dos rejeitos radioativos gerados pelas centrais nucleares em operação no país. Além da necessidade de se atender requisitos de segurança quanto à geologia, hidrogeologia, ecologia, projeto e construção do repositório, a consulta à opinião pública é determinante para o sucesso da implantação de tal programa nuclear.

Os principais fatores contrários à opção nuclear dizem respeito à deposição dos rejeitos radioativos e às diferentes percepções dos riscos associados à energia nuclear (ELETRONUCLEAR, 2010).

No Brasil, a energia nuclear é empregada em setores como medicina diagnóstica e terapêutica, pesquisa científica, agricultura, irradiação de alimentos, controle de qualidade e verificação de danos nas indústrias, além de geração de energia elétrica. Em todas essas atividades são gerados rejeitos radioativos na fase de produção ou na fase de utilização das substâncias radioativas e, muitas vezes, em ambas.

Rejeitos radioativos podem ser classificados segundo vários critérios. A Agência Internacional de Energia Atômica (IAEA), em sua publicação recente Classification of radioactive waste (IAEA, 2009), adota a classificação dos rejeitos em 6 categorias, baseada no nível de atividade, meia-vida e forma de deposição final :

(1) Rejeitos isentos: rejeitos que satisfazem os critérios de dispensa, isenção ou exclusão de controle regulatório para fins de proteção radiológica;

(2) Rejeitos de meia-vida muito curta: rejeitos que podem ser armazenados para decaimento durante um período limitado de tempo, de até poucos anos, para subsequente descarte ou uso sem controle regulatório; enquadram-se nessa categoria basicamente os radionuclideos de meia-vida muito curta frequentemente utilizados na pesquisa e medicina. 
(3) Rejeitos de muito baixo nível: rejeitos que não atendam necessariamente aos critérios da categoria de rejeitos isentos, mas que não necessitam cuidados especiais para sua contenção e isolamento, podendo ser depositados em trincheiras próximos à superfície com limitado controle regulatório; eventualmente, podem conter quantidade muito limitada de radionuclídeos de meia-vida não muito curta.

(4) Rejeitos de nível baixo: rejeitos com atividade acima dos níveis de dispensa, com quantidade limitada de radionuclídeos de meia-vida longa. Podem ser depositadas em repositórios próximos à superfície, mas requerem barreiras robustas para contenção e isolamento da biosfera por algumas centenas de anos. Essa classe engloba uma grande variedade de rejeitos, podendo incluir radionuclideos de meia-vida curta com níveis altos de atividade e também radionuclídeos de meia-vida longa, porém em concentrações de atividade relativamente baixas.

(5) Rejeitos de nível intermediário: rejeitos que requerem grau de contenção e isolamento maiores do que os rejeitos de nível baixo, principalmente pelo seu conteúdo de radionuclídeos de meia-vida longa, devendo ser depositados em repositórios mais profundos, da ordem de dezenas a centenas de metros sob a superfície.

(6) Rejeitos de nível alto: rejeitos com níveis de concentração de atividade suficientes para gerar quantidades significativas de calor por decaimento radioativo ou rejeitos com quantidade significativa de radionuclídeos de meia-vida longa que demandam deposição em formações geológicas estáveis, a várias centenas de metros de profundidade.

A AIEA recomenda que cada país defina os seus próprios limites quantitativos para cada classe de rejeitos.

No Brasil, a Comissão Nacional de Energia Nuclear define rejeito radioativo como sendo "qualquer material resultante de atividades humanas que contenha radionuclídeos em quantidades superiores aos limites de isenção, estabelecidos pela CNEN, para o qual a reutilização é imprópria ou não prevista" (CNEN, 2011). A CNEN tem definido uma classificação de rejeitos análoga à da AIEA, com 
valores limites para cada classe, porém ainda não publicada na forma final de Resolução. Não existem rejeitos de atividade alta no Brasil; todos eles se enquadram nas demais classes, sendo armazenados em depósitos iniciais nos centros geradores, ou nos depósitos intermediários localizados nos diversos centros de pesquisa subordinados à Comissão Nacional de Energia Nuclear.

Desenvolvimentos recentes da ciência e tecnologia têm colocado novos desafios referentes a como deve ser o processo decisório sobre políticas de ciência e tecnologia. A população passou a exigir mais informações sobre os riscos e maior participação nas decisões e debates sobre o tema. Visando reduzir a oposição da sociedade, os processos de gerenciamento de riscos em países democráticos têm procurado integrar ciência, economia e valores sociais e culturais, incorporando a opinião pública nos debates e decisões. Uma etapa essencial dos processos decisórios é o gerenciamento de riscos, e é nela que está situado o entendimento da natureza dos riscos e os julgamentos sobre sua aceitabilidade (Figura 1). A base dos dilemas sociais do gerenciamento são as divergências entre o público e especialistas no conceito do que seria um risco aceitável. $E$ foram estas mesmas divergências que impulsionaram os estudos de percepção de risco e comunicação de riscos (ROCCA, 2002; SJÖBERG, 2004b).

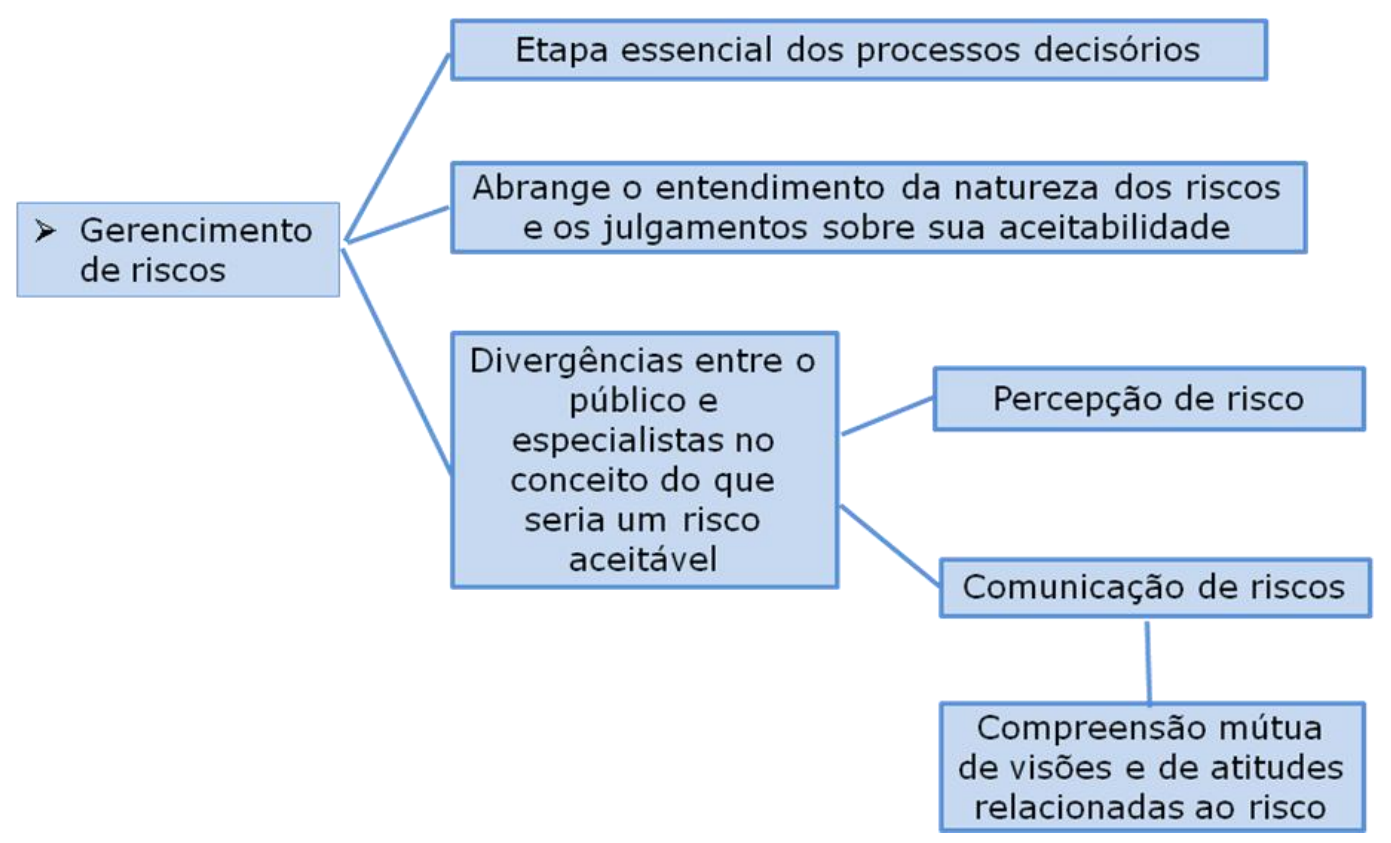

Figura 2 A percepção de risco como parte do gerenciamento de riscos 
Para uma comunicação de riscos eficaz entre tomadores de decisão e o público, é necessária uma compreensão mútua de visões, assim como de atitudes relacionadas ao risco (SKB, 2006). Faz-se uso da pesquisa de opinião pública para entender a percepção de risco das pessoas, com o propósito de se avaliar crenças e atitudes relacionadas (SJÖBERG, 2004a).

Vários países realizaram pesquisas de opinião (IRSN, 2009; SKB, 2006) na tentativa de identificar as principais fontes de rejeição à energia nuclear. Neste trabalho é apresentado um modelo de pesquisa de percepção de risco aplicado ao caso dos rejeitos radioativos, juntamente com os subsídios teóricos de sua organização.

Está em curso, no Brasil, um projeto de construção de um repositório de rejeitos radioativos e de cooperação técnica com a Agência Internacional de Energia Atômica no sentido de se selecionar possíveis locais para a disposição final de rejeitos radioativos. Para tal projeto obter sucesso é necessário que ocorra um programa de comunicação de risco efetivo, e para isso, é indispensável a compreensão da percepção de risco, já que esta conduz o comportamento da pessoa (ROHRMANN, 2008). 


\section{OBJETIVOS}

Este trabalho tem como objetivo propor um questionário para ser aplicado nos municípios candidatos à construção do repositório nacional de rejeitos radioativos, focado na questão da aceitabilidade da energia nuclear e sua associação com a gestão de rejeitos radioativos. Os seguintes fatores explicativos deverão ser abordados no questionário: atitudes em relação à energia nuclear e aos rejeitos radioativos, credibilidade das instituições e setores responsáveis pela segurança nuclear, identificação dos benefícios percebidos; percepção do risco de determinadas tecnologias e atividades, percepção do risco real, compreensão das reações emocionais e princípio da precaução. 


\section{PERCEPÇÃO DE RISCO}

Risco tem sido definido de várias maneiras e todos seus conceitos possuem um elemento em comum: a distinção entre realidade e possibilidade. Como incerteza e risco estão intimamente relacionados, e as ações e compreensões relativas a risco são aprendidas através de concepções e avaliações cultural e socialmente estruturadas do mundo, do que ele parece e o que ele deveria ou não ser, risco significa diferentes coisas para cada pessoa (SJÖBERG et al, 2004).

De acordo com Beck (1999), o conceito de risco é caracterizado por um estado peculiar intermediário entre segurança e destruição, onde a percepção dos riscos determina pensamento e ação. Para ele, a percepção e a definição cultural constituem o risco. $O$ autor também assume que os riscos pressupõem decisões, ou seja, os riscos emergem da transformação de incertezas e perigos em decisões (e determinam as tomadas de decisões, que por sua vez produzem riscos).

Consoante Renn (2008), todos os conceitos de risco possuem uma précondição: a eventualidade das ações humanas. E para ele a definição de risco contém três elementos: resultados que têm impacto sobre o que os seres humanos valorizam, a probabilidade de ocorrência (incerteza) e um contexto específico no qual o risco pode se materializar. Um indivíduo, uma organização ou a sociedade enfrenta várias opções para tomar uma ação (incluindo não fazer nada), e cada uma delas está associada com potenciais consequências, positivas ou negativas. Se a natureza contingente de tal ação é tida como certa, o termo 'risco' denota a probabilidade de que um estado indesejável da realidade (efeitos adversos) ocorra como resultado de eventos naturais ou atividades humanas. Consequências podem ser alteradas através da modificação da atividade ou evento inicial ou pela atenuação dos impactos.

Percepção de risco, conforme Rohrmann (2008), refere-se aos julgamentos e avaliações das pessoas com relação aos perigos a que elas estão ou poderiam estar expostas. Tais percepções orientam decisões de aceitabilidade dos riscos. A maneira como a importância dos riscos é avaliada, e até que ponto as pessoas estão preparadas para aceitar um risco, é dependente do tipo de perigo, das 
experiências pessoais, crenças e atitudes, e de diversas influências sociais. Características técnicas e estatísticas de risco não podem explicar os dados de aceitação do risco. Ainda segundo o autor, a aceitação ou oposição aos riscos não é determinada pelo conhecimento, ou falta dele, mas sim pelas discrepâncias de valores pessoais.

Guimarães (1999) destaca percepção de riscos como sendo um "conjunto de fenômenos de natureza sociológica e psicológica que criam uma hierarquia de riscos subjetivos, particular a cada indivíduo e a cada grupo social”, sendo risco subjetivo a expectativa de consequências indesejáveis determinada pela percepção de risco subjetiva de indivíduos e coletividades acerca da probabilidade e a gravidade dos perigos dele decorrentes. A percepção de riscos coletiva (ou social) tende a avaliar os riscos subjetivos superestimando a gravidade e subestimando as probabilidades. A percepção individual, por outro lado, é influenciada pela avaliação ao nível psicológico e nem sempre racional quanto aos benefícios e riscos.

Starr (1969) foi quem desenvolveu os primeiros estudos sobre risco percebido. Ele diferenciou o nível de risco tecnológico aceitável considerado pela sociedade, com base numa análise histórico-econômica dos riscos e benefícios das diversas tecnologias, assumindo que os registros dos acidentes e o preço das diversas tecnologias podiam revelar, de uma forma adequada, as opções ou preferências de uma sociedade e permitir a predição de tendências sociais futuras. Como medidas de custos de tecnologia, foi utilizado o risco associado a essa tecnologia, isto é, a probabilidade estatística de morte por hora de exposição do indivíduo à atividade ou tecnologia considerada. Já como medida de benefício, foi operacionalizado a sua conversão em dólares/ano por indivíduo e foi utilizado o preço médio por hora dessa atividade; no caso de atividades involuntárias, o aumento do rendimento anual por pessoa derivado da utilização dessa tecnologia. Starr chegou nas seguintes conclusões: 1) quanto mais benefícios uma atividade ou tecnologia apresenta, maiores os riscos que a sociedade está disposta a enfrentar, 2) ocorre uma maior aceitabilidade de correr riscos se considerado atividades voluntárias ao invés de atividades involuntárias com o mesmo nível de 
benefícios e 3) o nível de risco tolerado para atividades voluntárias é semelhante ao risco de morte por doença.

A abordagem de preferência revelada recebeu várias críticas porque assumia que as pessoas possuiam toda a informação acerca da atividade questionada e não levavam em consideração o caráter afetivo que as pessoas poderiam ter por determinada atividade ou tecnologia. Assim, Fischhoff et al (1978) delinearam um estudo análogo ao de Starr pedindo diretamente às pessoas para exprimirem as suas preferências face aos riscos e benefícios de trinta tecnologias e atividades. Neste estudo, não foi pedido apenas avaliações de risco e benefício, também foi solicitado às pessoas para avaliarem as tecnologias tendo em conta nove características ou dimensões qualitativas. São elas: 1) Voluntário - Involuntário, 2) Efeitos imediatos - efeitos retardados, 3) Conhecimento para as pessoas expostas - desconhecimento, 4) Conhecimento para a ciência - desconhecimento, 5) Controlável - incontrolável, 6) Novo antigo, 7) Crônico - catastrófico, 8) Comum - terrível, 9) Consequências pouco graves - consequências fatais. Este paradigma de investigação é designado por paradigma psicométrico ou abordagem das preferências expressas ou modelo psicométrico.

O modelo psicométrico é orientado para explicar a percepção e a aceitabilidade do risco, não a atitude perante a tecnologia per se (SJÖBERG, 2002).

Slovic e colaboradores (2001) replicaram e estenderam o estudo de Fishhoff et al. (1978) a noventa tecnologias, avaliadas em 18 dimensões. A análise fatorial permitiu a obtenção de dois grandes fatores: risco assustador (dread) e familiaridade. Risco assustador mostrou uma associação entre a controlabilidade do risco e a sua gravidade. Familiaridade demonstrou que riscos com efeitos observáveis e consequências imediatas são também considerados como conhecidos para a ciência e para aqueles que julgaram os efeitos e as consequências do risco de tal maneira.

Através das técnicas psicométricas, os pesquisadores vem se esforçando para identificar semelhanças e diferenças entre grupos em relação à percepção de 
risco, demonstrando que a concepção de risco é diferente entre as pessoas. Quando especialistas avaliam o risco, seus julgamentos correlacionam com estimativas técnicas de fatalidades anuais. Por outro lado, as pessoas leigas, quando questionadas, podem até acessar dados sobre fatalidades anuais, mas seus julgamentos estão mais relacionados a outras características de perigo (potencial catastrófico por exemplo) (SLOVIC, 1987).

O risco pode ser diferenciado de várias maneiras. Uma delas é distinguir entre risco pessoal e geral, ou seja, risco para si e para os outros. Foi encontrado, num estudo recente, realizado em três amostras aleatórias da população sueca, que a política em relação à mitigação do risco (para um conjunto de 19 perigos) era impulsionada principalmente pelo risco geral no caso de riscos de estilos de vida (fumo, consumo de álcool etc), enquanto que no caso de tecnologia ou perigos ambientais era mais fortemente impulsionada pelo risco pessoal (SJÖBERG, 2003a). Outra distinção possível é entre risco de uma atividade ou tecnologia e o risco da lesão causada por ela. Verificou-se, empiricamente, que o risco da lesão era mais importante que o risco de uma atividade, projetando na explicação das atitudes em relação à política de mitigação de risco (SJÖBERG, 2002).

Segundo Schmidt (2004), riscos conhecidos são mais aceitos que os desconhecidos. Ainda segundo este autor, a percepção de risco é atenuada se o risco é escolhido voluntariamente, mas amplificada se é imposto. Mesmo que os riscos sejam parecidos, o risco escolhido voluntariamente é mais aceitável que o imposto já que envolve liberdade de escolha e a autonomia e responsabilidade própria. $\mathrm{O}$ autor ainda defende que os riscos que são percebidos como estando sob o controle de um determinado indivíduo são mais aceitáveis que os riscos percebidos como estando sob o controle de outros, pois não sendo capaz de manter o controle da situação, cria-se um sentimento de impotência e desamparo.

$O$ fato de algumas pessoas afirmarem estar menos sujeitas ao risco do que os outros, segundo Sjöberg (2000a), pode ser denominado negação do risco e o nível de negação do risco está relacionado com as atitudes. 
$\mathrm{Na}$ área nuclear, a percepção de risco é um aspecto importante, e vários fatores têm sido propostos para explicá-la (SJÖBERG, 2000a).

Um desses fatores é a atitude em relação ao agente gerador do risco, fator este bastante difundido em estudos de percepção de risco. Considerando os rejeitos radioativos, a atitude para energia nuclear parece ser uma determinante importante, pois se correlaciona fortemente com o risco percebido do rejeito radioativo. Em outras palavras, atitudes determinam o risco percebido (Sjöberg, 1998). Atitude é uma função de crenças, e por esse motivo, a percepção de risco pode ser estudada por métodos razoavelmente bem desenvolvidos de medição de atitudes (SJÖBERG, 2000a, 2000d). Uma crença é um julgamento de probabilidade que vincula algum objeto ou conceito a algum atributo. Os termos 'objeto' e 'atributo' estão num sentido genérico e ambos os termos podem se referir a qualquer aspecto discriminável do indíviduo. Em suma, assim como a atitude é determinada pelo conjunto de crenças que uma pessoa sustenta, uma atitude só serve para predispor a pessoa a se envolver em um conjunto de comportamentos que, quando tomados em conjunto, são consistentes com a atitude (IAEA, 1976).

Uma atitude é essencialmente um julgamento subjetivo em que se gosta ou não de determinado objeto, se este é bom ou ruim, ou de se sentir favorável ou desfavorável a ele. Pode-se ter atitudes com relação a conceitos, pessoas, instituições, eventos, comportamentos, resultados, etc (IAEA, 1976). Atitudes de risco são as intenções das pessoas para avaliarem uma situação de risco de modo favorável, ou não, e agirem de acordo (ROHRMANN, 2008).

$O$ conceito de estigma tem sido sugerido como uma atitude particularmente forte e preconceituosa com relação a uma tecnologia (SJÖBERG and DROTTZSJÖBERG, 2008). Um elo fundamental do estigma com a percepção de risco é através da confiança, de modo que, se a confiança, por exemplo, nos especialistas, gestores e políticos aumenta, o risco percebido diminuirá, e consequentemente, o estigma diminui (KUNREUTHER and SLOVIC, 1999).

Sjoberg (2001) alega que confiança é outro fator explicativo da percepção de risco. Entretanto, dados a respeito são limitados, visto que a maioria dos 
estudos de confiança lidam apenas com a componente confiança social, ou seja, confiança nos especialistas e cientistas; não levam em consideração a componente confiança epistêmica (confiança na ciência por trás da tecnologia em questão, no conhecimento sistemático acumulado), que, ainda segundo o autor, é a componente mais promissora das duas. As pessoas podem confiar nos especialistas, e ainda assim, não acreditar que a ciência tenha respostas conclusivas e completas para todas as questões levantadas na avaliação de risco de perigos, como os associados com os rejeitos nucleares (SJÖBERG, 2004b). Além de falta de confiança (seja social ou epistêmica) pode existir a crença na existência de interesses e objetivos contrários (antagonismo) (SJÖBERG and HERBER, 2008). O antagonismo é visto como hostil para o bem-estar do público (SJÖBERG, 2008).

A partir das inúmeras hipóteses propostas por Sjöberg (2008) foi verificado que 1) o antagonismo é uma determinante útil da confiança; 2) o antagonismo está positivamente relacionado com o risco percebido e; 3) a confiança epistêmica é um fator explicativo importante no risco percebido, mais até do que a confiança social.

Mais um fator explicativo da percepção de riscos é a percepção dos benefícios, e ambos não devem ser analisados separadamente. A aceitação de um dado risco está estritamente relacionada aos benefícios esperados da atividade que apresenta o risco, seja consciente ou inconscientemente. $O$ conceito de aceitação do público está fortemente vinculado ao conceito de benefício, e não ao conceito de risco. Segundo Touzet et al (2000), os riscos não são aceitos numa condição absoluta, mas estão relacionados aos benefícios percebidos, incluindo o contexto e, sobretudo, confiança nos responsáveis pela prática. Os riscos percebidos como tendo benefícios claros são mais aceitos do que os riscos percebidos como tendo pouco ou nenhum benefício (SCHMIDT, 2004).

Outro conceito útil para avaliar ou fundamentar o risco percebido é o risco real, porque consoante Sjöberg (1995), até certo ponto, risco percebido é um reflexo do risco real, especialmente quando os riscos são desconhecidos. É 
esperado uma percepção sensata dos riscos com os quais as pessoas possuem alguma experiência, direta ou indireta (SJÖBERG, 2000a).

O princípio da precaução corresponde à ética necessária em um contexto de incerteza e afirma-se em duas hipóteses: 1) a possibilidade que condutas humanas causem danos coletivos vinculados a situações catastróficas que podem afetar o conjunto de seres vivos e 2) a falta de evidência científica (incerteza) a respeito da existência do dano temido. Incerteza não somente na relação de causalidade entre $\mathrm{o}$ ato a suas consequências, mas quanto à realidade do dano, a medida do risco ou do dano. O princípio da precaução atua para inibir o risco de um perigo e sua prática demanda o exercício da dúvida (HAMMERSCHMIDT, 2002). Sjöberg (2009) explica que o princípio da precaução reflete na confiança epistêmica e na severidade de consequências, e que quando adicionado a algum modelo de percepção de risco, estabelece um importante poder explicativo ao modelo. De acordo com Sjöberg (2009a), as pessoas tendem a exibir um alto nível de concordância com os itens de precaução e rejeitar os itens a favor de correr riscos, de modo que, o princípio da precaução afeta as atitudes e a percepção acerca de um risco.

Sjöberg (2007) encontrou que existe uma forte e consistente relação entre as reações emocionais e a percepção do risco. As emoções à que este estudo se refere são aquelas experimentadas pelo respondente, não as emoções atribuídas aos outros. As emoções negativas exercem um papel considerável, mas as emoções positivas (ou falta de tais emoções) também. As pessoas reagem emocionalmente a ameaças, às vezes fora da proporção com a ameaça real, revelando "reações instintivas" e formando atitudes rígidas, difíceis de serem mudadas por meio de informações. Entende-se que nos processos em que há participação do público é possível que as reações contrárias sejam amenizadas (SJÖBERG, 2003). 


\section{METODOLOGIAS DE PESQUISAS DE OPINIÃO}

Uma pesquisa de opinião é um processo de investigação no qual uma informação é coletada a partir de uma parte da população (amostra), com o propósito de fazer inferências sobre esta população. A forma mais habitual de se realizar uma pesquisa de opinião é através de questionários, que podem ser aplicados seguindo várias metodologias: entrevista por telefone, entrevista cara-acara, via correio ou via e-mail (Hill \& Hill, 2009).

A maneira como as questões são redigidas no questionário são um fator importante na explicação das respostas a uma pesquisa de opinião, independente do método de aplicação (SJÖBERG, 2000).

Num questionário, frequentemente todas as variáveis são medidas a partir das perguntas, e em vista disso, é necessário decidir, no momento de elaboração do mesmo, quais perguntas empregar para medir as variáveis explicativas, o tipo de resposta de cada pergunta (aberta ou fechada), o tipo de escala de medida das respostas e os métodos corretos para analisar os dados coletados.

A diferença entre resposta aberta ou fechada reside na forma como a resposta é dada e cada uma delas possui vantagens e desvantagens. Nas perguntas abertas, o entrevistado responde com suas próprias palavras e, no caso das perguntas fechadas, escolhe entre respostas alternativas previamente enunciadas. As perguntas abertas podem oferecer informação mais "rica" e detalhada, entretanto, muitas vezes as respostas têm de ser interpretadas, gastase mais tempo para codificá-las e é difícil analisá-las de uma forma estatisticamente mais elaborada. As respostas das perguntas fechadas são facilmente analisadas por métodos estatísticos, mas pode acontecer da informação contida nas respostas ser pouco "rica" ou conduzir a conclusões simples demais.

Um questionário que só contenha perguntas abertas é útil quando: o investigador não tem tempo nem facilidade para entrevistar, não há muita literatura sobre o tema de investigação, a literatura não dá indicação das variáveis mais relevantes ou o questionário pretende obter informação predominantemente 
qualitativa. Um questionário só com perguntas fechadas é útil quando: o investigador conhece bem a natureza das variáveis relevantes e quer obter informação quantitativa sobre elas; ou quando o investigador quer criar uma nova variável a partir de um conjunto de perguntas sobre vários aspectos já conhecidos.

É possível também um questionário que contenha perguntas abertas e fechadas, mas ele só é útil quando se pretende obter informação qualitativa para complementar e contextualizar a informação quantitativa obtida pelas outras variáveis (Hill \& Hill, 2009).

\subsection{Escalas de medida}

De acordo com Hill \& Hill (2009), quando o questionário possui perguntas fechadas, é necessário escolher um conjunto de respostas alternativas para cada uma destas perguntas. Os tipos de escala mais utilizados em questionário são:

- Escalas nominais;

- Escalas ordinais;

- Escalas de intervalo;

- Escalas de rácio.

\subsubsection{Escalas nominais}

Este tipo de escala resume-se num conjunto de categorias de resposta qualitativamente e mutuamente exclusivas. Por exemplo:

a) Feminino, masculino;

b) Menor de 16 anos, 16 - 24 anos, 25 - 29 anos, 30 - 39 anos, $40-49$ anos, 50 anos ou mais .

Quando se usa uma escala nominal para medir uma variável, só é razoável calcular frequências (número de respostas) em cada uma das categorias.

\subsubsection{Escala ordinal}

Este tipo de escala permite uma ordenação numérica das suas categorias, ou seja, das respostas alternativas, estabelecendo uma relação de ordem entre 
elas. Contudo, não é possível medir a magnitude das diferenças entre as categorias.

São dois tipos de pergunta que utilizam respostas dadas numa escala ordinal. No tipo 1, são apresentados um conjunto de itens e o entrevistado deve avaliar uns em relação aos outros, ou seja, ele deve ordenar os itens. Como no caso abaixo, só há uma variável, a importância atribuída. Exemplo: " Coloque em ordem os itens seguintes em termos do grau de importância que Ihes atribui (4 para o item mais importante, 3 para o item de importância seguinte... 1 para o item menos importante)."

\begin{tabular}{|c|c|}
\hline Item & Grau de importância \\
\hline Ter trabalho interessante & \\
\hline Ter um salário alto & \\
\hline Ter bons colegas no local de trabalho & \\
\hline Ter segurança no emprego & \\
\hline
\end{tabular}

Os itens não são variáveis, são características dadas.

No tipo 2, o entrevistado precisa avaliar um só item em termos de uma variável, como no exemplo: "Em que medida está satisfeito ou insatisfeito no seu emprego?

\begin{tabular}{|c|c|c|c|c|}
\hline Muito insatisfeito & Insatisfeito & $\begin{array}{c}\text { Nem satisfeito } \\
\text { nem insatisfeito }\end{array}$ & Satisfeito & Muito satisfeito \\
\hline 1 & 2 & 3 & 4 & 5 \\
\hline
\end{tabular}

\subsubsection{Escalas de intervalo}

Este tipo de escala possui a característica de uma escala ordinal em que um valor numérico mais elevado na escala indica uma quantidade maior da variável medida. Contudo, possui uma característica adicional - as diferenças entre valores numéricos adjacentes na escala indicam diferenças iguais na quantidade da variável medida. É possível entender esta característica facilmente por meio do exemplo de duas escalas de temperatura, como a Centígrada e a escala Fahrenheit. Ambas escalas de temperatura são escalas de intervalo. No 
quadro encontram-se quatro valores de temperatura na escala Centígrada e o correspondente equivalência na escala Fahrenheit, que pode ser calculada pela transformação linear dada pela equação 1 :

$$
{ }^{\circ} F={ }^{\circ} C \frac{9}{5}+32
$$

É importante notar que a diferença entre dois valores adjacentes na escala Centígrada (por exemplo, entre 0 e 10 ou entre 20 e 30) é de 10 graus, ou seja, a diferença de quantidade de calor entre $0^{\circ} \mathrm{C}$ e $10^{\circ} \mathrm{C}$ é igual à diferença de quantidade de calor entre $20^{\circ} \mathrm{C}$ e $30^{\circ} \mathrm{C}$. Na Fahrenheit, os valores numéricos são diferentes, mas as diferenças entre dois valores adjacentes também são iguais (a diferença é de 18 graus). Ou seja, as escalas lineares obedecem uma relação linear.

\begin{tabular}{|l|c|c|c|c|}
\hline Temperatura Centígrado $\left({ }^{\circ} \mathrm{C}\right)$ & 0 & 10 & 20 & 30 \\
\hline Temperatura Fahrenheit $\left({ }^{\circ} \mathrm{F}\right)$ & 32 & 50 & 68 & 86 \\
\hline
\end{tabular}

\subsubsection{Escalas de rácio}

Estas escalas têm todas as características das escalas de intervalo e mais uma característica adicional. O valor zero não é arbitrário, é absoluto ou real. Por causa disso, é possível fazer inferências sobre uma relação entre valores numa escala de rácio. "Quanto anda por dia?"

\begin{tabular}{|c|c|c|c|c|}
\hline A & B & C & D & E \\
\hline 0 metro & 10 metros & 20 metros & 30 metros & 40 metros \\
\hline
\end{tabular}

A distância entre a opção $A$ e $B$ é de 10 metros, a distância entre $A$ e $E$ é de 40 metros, portanto, parece que a distância da opção E é 4 vezes maior do que a distância na opção $B$. Isto significa que o rácio entre a distância $(A-E)$ e a distância $(A-B)$ é 4:1.

Entre variáveis mais comumente medidas por meio de escala de rácio pode-se citar tempo e distância. 


\subsection{Sobre as respostas}

\subsubsection{O número de respostas alternativas}

É normal que o número de respostas alternativas esteja entre 2 e 9 . O número ótimo vai depender principalmente de três fatores:

- do objetivo da pergunta;

- da forma da pergunta;

- da natureza dos entrevistados.

Quando a pergunta solicita fatos, e a forma da pergunta só permite duas respostas possíveis, é óbvio que deve-se utilizar só duas respostas alternativas. Por exemplo, para saber o sexo do entrevistado.

Mas quando a pergunta solicita uma opinião, uma atitude ou um grau de satisfação, não se deve utilizar só duas alternativas de resposta. A maioria dos respondentes quer normalmente dar uma resposta mais detalhada (o que é útil para o investigador) (Hill \& Hill, 2009).

Em um estudo metodológico, foram investigadas as propriedades de vários formatos de resposta utilizada para estudar a percepção de risco. Foi verificado que alguns deles fornecem dados mais eficientes para a discriminação entre os perigos. É preferível as escalas de categorias com um número limitado de alternativas, como 5 ou 7 , pois excesso de categorias pode confundir as pessoas (Sjöberg, 1994; Sjöberg, 2000).

\subsubsection{A ordem dos valores numéricos associados às respostas}

Não importa se os valores associados às respostas têm a ordem crescente ou decrescente. O que importa é manter a ordem.

Também não importa os valores absolutos dos números associados às respostas, pois é possível transformar os valores depois da recolha dos dados, se for necessário. Mas, em geral, os respondentes preferem escalas de reposta que utilizem números positivos e há pessoas que não compreendem bem os números negativos. 


\subsubsection{A resposta 'não sei'}

Por vezes torna-se aconselhável (ou necessário) incluir a resposta 'não sei' em algumas perguntas. Normalmente isso acontece em perguntas que requerem um conhecimento específico do respondente sobre o tema da pergunta.

\subsection{Como medir uma variável latente}

Uma variável latente é uma variável que não pode ser observada nem medida diretamente, mas que pode ser definida a partir de um conjunto de outras variáveis componentes (possíveis de serem observadas ou medidas) que medem alguma qualidade em comum. As variáveis componentes podem ser medidas a partir de perguntas de um questionário. A estas perguntas dá-se tecnicamente 0 nome de itens do questionário.

O processo de construção de um questionário para medir uma variável latente pode ser feito em duas etapas principais:

- seleção de itens apropriados para definir a variável latente;

- determinação da adequacidade do questionário.

A etapa de seleção de itens pode ser subdividida em nove sub-etapas:

1. Define-se um conjunto de variáveis componentes, a partir da literatura disponível e conhecimento de estudo sobre o tema ou, caso não haja teoria relevante ou não existam estudos empíricos, usando o senso comum e a intuição.

2. Para cada uma das variáveis componentes, elaboram-se entre 4 a 6 itens; estes itens devem ter a forma de perguntas fechadas. Para medir atitudes, é costume usar afirmações em vez de perguntas e a escala de resposta deve ser do tipo 1 = discordo totalmente, 2 = discordo, 3 = indeciso, $4=$ concordo, 5 = concordo totalmente. Este tipo de escala é conhecida como escala de Likert.

3. Nesta sub-etapa aplica-se este conjunto de itens a uma amostra estatisticamente representativa.

4. Obtém-se um valor para cada respondente e para cada item. Na atribuição de valores aos itens, é necessário decidir se para esse item um valor 
elevado corresponde a concordância ou discordância. Caso seja necessário utilizar uma orientação contrária a dos valores enunciados na questão, inverte-se os valores. Para cada respondente os valores atribuídos a cada item são somados, obtendo-se o valor total da variável.

5. Calculam-se as correlações item-total, ou seja, as correlações entre os valores atribuídos a cada item e o valor total para o conjunto dos itens. Estatisticamente, deve existir uma correlação relativamente forte $(>0,6)$ entre cada item e o total e esta correlação deve ser estatisticamente significativa.

6. Calcula-se as correlações entre itens. Estas correlações devem ser relativamente elevadas $(>0,6)$ e os valores devem ser todos positivos e significativos, pois se assumiu que cada item mede alguma qualidade em comum com os outros itens, a variável latente.

7. Nesta sub-etapa analisam-se os valores das correlações item-total e entre itens. Removem-se do questionário os itens que não apresentam correlações relativamente elevadas ou significativas com o valor total, bem como os que não se correlacionem adequadamente com os outros itens, pois significa que estes não apresentam contribuição suficiente para definir a variável latente que se pretende medir.

8. Selecinam-se os melhores itens para cada variável componente dentre aqueles que apresentaram correlações item-total e entre itens adequadas. O ideal é que o número de itens escolhidos seja o mesmo para todas as variáveis componentes.

9. Para verificar se o questionário mede apenas uma variável latente, ou seja, se ele é unidimensional, pode-se utilizar a técnica estatistica Análise Fatorial.

Confiabilidade é definida como sendo o grau com que as medições estão isentas de variâncias de erros aleatórios. Existem várias fórmulas para estimar a confiabilidade dos questionários, e uma delas é a estimativa alfa de Cronbach, também conhecida como estimativa de consistência interna. A fórmula para a estimativa de confiabilidade de Cronbach é: 


$$
\alpha=\left(\frac{k}{k-1}\right) \cdot\left(1-\frac{\text { soma das var iâncias de cada item }}{\text { var iância total dos } k \text { itens }}\right) \text { (HAYES, 1996) }
$$




\section{QUESTIONÁRIO}

Diversos estudos (SLOVIC, 1996; DROTTZ-SJÖBERG and SJÖBERG, 1990; NSC, 1993; GARRICK, 1991) já apontavam para a relevância da percepção e comunicação de riscos para o processo decisório e também indicavam o seu papel na amplificação das conseqüências em situações de acidentes (DROTTZSJÖBERG and SJÖBERG, 1990; PETTERSON, 1988).

Para a abordagem dos objetivos deste estudo, optou-se por um modelo flexível de pesquisa de percepção de risco, aplicado ao caso dos rejeitos radioativos.

Este trabalho baseou-se principalmente nos estudos efetuados por Sjöberg (SKB, 2006), concentrando-se na identificação dos fatores que explicam a percepção e as atitudes em relação à energia nuclear e, mais particularmente, aos rejeitos radioativos, e na avaliação da credibilidade das instituições e setores relacionados à energia nuclear.

O questionário proposto é formado por oito blocos de perguntas agrupadas de acordo com os objetivos defenidos para este estudo. O primeiro bloco destinado ao estudo das atitudes em relação aos rejeitos radioativos e à energia nuclear é composto de dez questões com alternativas de respostas fechadas. $O$ segundo bloco que analisa a confiança, definida como a expectativa de uma pessoa apoiar-se em condutas competentes e previsíveis de indivíduos e instituições, apresenta seis questões de alternativas fechadas e a possibilidade de resposta 'não sei'. No terceiro bloco há duas questões relativas aos benefícios, na tentativa de identificar se o público se mostra mais preocupado com atividades cujos benefícios não são claros. O quarto bloco realiza a abordagem psicométrica, ou abordagem das preferências expressas, através de cinco questões em que é solicitada a avaliação de determinadas tecnologias e atividades para cada uma das características ou dimensões em particular; nas questões dentro deste bloco, a sensibilidade ao risco é utilizada para medir as diferenças na tendência de avaliar todos os riscos como grandes ou pequenos. O quinto bloco trata do risco real, pois é um conceito útil para explicar o risco percebido (Sjöberg, 2000a). O 
sexto bloco extrai subsídios para o entendimento das reações emocionais. O sétimo bloco examina o princípio da precaução e o último bloco é destinado a conhecer o perfil do entrevistado.

Em todas as questões foram utilizadas escalas de Likert. Nas questões em que se exige um conhecimento prévio, há a opção "não sei".

\subsection{Primeiro bloco}

As duas primeiras questões visam conhecer as atitudes, essencial para a proposta de comunicação de risco sugerida neste trabalho. Na primeira questão, o entrevistado deve responder se sente-se extremamente negativo em relação a um repositório de rejeitos radioativos em seu município ou se extremamente positivo. Na segunda pergunta, o entrevistado é questionado se está comprometido com a questão do repositório no município. Optou-se por utilizar o termo "depósito", em vez de "repositório", para facilitar o entendimento da pergunta por parte do público leigo no assunto, sem prejuízo de sentido.

1. Como se sentiria em relação a um depósito de rejeitos radioativos localizado em seu município?

(1)

Extremamente negativo
(2)

(3)

(4)

(5)

(6)

Extremamente positivo

2. Se um depósito viesse a ser localizado em seu município, qual seria seu grau de envolvimento com a questão?

(1)

Completamente não envolvido
(2)

(3)
(4)

(5)

6)
(7)

Completamente envolvido

As questões 3, 4, 5 e 6 averiguam a negação do risco, ou seja, o fato das pessoas geralmente afirmarem estar menos sujeitas a riscos do que os outros (Sjöberg, 2003). O nível de negação do risco está relacionado com as atitudes (Sjöberg, 2000a). 
3. Acha que um depósito de rejeitos radioativos traria algum tipo de risco para o município?

(1)

Não, absolutamente não
(2)

(3)

(4)

(5)

(6)
(7)

Sim, absolutamente

4. Acha que um depósito de rejeitos radioativos traria algum tipo de risco para você?

(1)

Não, absolutamente

não
(2)

(4)

(5)

(6)

Sim, absolutamente sim

5. Acredita que seria capaz de proteger-se contra um possível acidente no depósito?

(1)

Não, absolutamente não
(2)

(4)

(5)

(6) (7) Sim, absolutamente $\operatorname{sim}$

6. Acredita que os moradores de seu município seriam capazes de se proteger contra um possível acidente no depósito?

(1)

Não, absolutamente

não
(2)

(3)

(4)

(5)

(6)

Sim, absolutamente

As questões 7, 8 e 9 tem como objetivo avaliar as crenças em relação a um repositório de rejeitos radioativos localizado no município, que refletem a posição a favor ou contrária a este. Assim como a atitude é determinada pelo conjunto de crenças que uma pessoa sustenta, uma atitude só favorece para predispor a pessoa a se envolver em um conjunto de comportamentos que, quando tomados em conjunto, são consistentes com a atitude (IAEA, 1976). 
7. Considerando a aceitação de um depósito em seu município, julgue as seguintes afirmações.

\begin{tabular}{|c|c|c|c|c|c|c|c|}
\hline \multirow{2}{*}{$\begin{array}{l}\text { O país seria beneficiado com a } \\
\text { construção do depósito em } \\
\text { município. }\end{array}$} & \multicolumn{2}{|c|}{$\begin{array}{l}\text { Não, } \\
\text { lutamente } \\
\text { não }\end{array}$} & & & & & $\begin{array}{l}\text { Sim, } \\
\text { lutamente } \\
\text { sim }\end{array}$ \\
\hline & (1) & (2) & (3) & (4) & (5) & (6) & (7) \\
\hline $\begin{array}{l}\text { O depósito traria benefícios econômicos } \\
\text { ao município. }\end{array}$ & (1) & (2) & (3) & (4) & (5) & (6) & (7) \\
\hline $\begin{array}{l}\text { Um depósito traria espírito de otimismo } \\
\text { para o município. }\end{array}$ & (1) & (2) & (3) & (4) & (5) & (6) & (7) \\
\hline $\begin{array}{l}\text { Empresas de outros setores poderiam se } \\
\text { instalar em seu município. }\end{array}$ & (1) & (2) & (3) & (4) & (5) & (6) & (7) \\
\hline
\end{tabular}

8. Considerando a oposição a um depósito em seu município, julgue as seguintes afirmações.

\begin{tabular}{|c|c|c|c|c|c|c|c|}
\hline \multirow[b]{2}{*}{ Um depósito traria riscos à saúde humana. } & \multicolumn{2}{|c|}{$\begin{array}{l}\text { Sim, } \\
\text { bsolutamente } \\
\text { sim }\end{array}$} & \multirow[b]{2}{*}{ (3) } & \multirow[b]{2}{*}{ (4) } & \multirow[b]{2}{*}{$(5)$} & \multicolumn{2}{|c|}{$\begin{array}{c}\text { Não, } \\
\text { absolutamente } \\
\text { não }\end{array}$} \\
\hline & $(1)$ & (2) & & & & (6) & (7) \\
\hline O município ficaria com uma imagem ruim. & (1) & (2) & (3) & (4) & (5) & (6) & (7) \\
\hline $\begin{array}{l}\text { Muitas pessoas se mudariam para outras } \\
\text { localidades. }\end{array}$ & (1) & (2) & (3) & (4) & (5) & (6) & (7) \\
\hline Muitas empresas deixariam o município. & (1) & (2) & (3) & (4) & (5) & (6) & (7) \\
\hline
\end{tabular}

9. Acha que um depósito de rejeitos radioativos pode fazer mal à saúde dos moradores locais?

(1)

Não, absolutamente

não
(2)

(3)

(4)

(5)

(6)

Sim, absolutamente $\operatorname{sim}$

A questão 10 verifica a noção de que um repositório de rejeitos radioativos traria estigma. Esta é uma opinião forte e não pode ser medida com as questões de atitude usuais. Nove declarações sobre um repositório de rejeitos radioativos são formuladas de maneira objetiva, de modo que fique expresso a preocupação 
do entrevistado acerca das implicações decorrentes do repositório de rejeitos radioativos.

10. Julgue as declarações abaixo referentes a um depósito de rejeitos radioativos em seu município.

Um depósito de rejeitos radioativos em meu município...

\section{Concordo}

totalmente

Seria totalmente inaceitável.

Seria vergonhoso.

Traria ao município uma imagem muito ruim.

Faria com que as empresas se mudassem.

Conduziria a graves conflitos entre as pessoas.

Seria uma forte preocupação para os moradores locais.

Faria-me mudar se tivesse a oportunidade.

Faria com que eu votasse em um partido contrário a essa decisão.
(1)

(1)

(1)

(1)

(1)

(1)

(1)

(1)
(2)

(2)

(2)

(2)

(2)

(2)

(2)

(2)
(3)

(3)

(4)

(4)

(5)

(6)

Discordo

totalmente

(7)
(7)
(5)
(6)

(7)

(3) (4) (5) (6)
(3)
(4)
(5)
(6)
(3)
(4)
(5)
(6)

(7)

(3) (4) (5) (6)

(3)

(4) (5)

(6)
(3)
(4)
(5)
(6)

(7)

\subsection{Segundo bloco}

A confiança nas pessoas e instituições é importante à medida que promove a crença no conteúdo de sua mensagem (Sjöberg, 2009). As questões 11 e 12 avaliam a confiança nas organizações e autoridades ligadas aos rejeitos radioativos. 
11. Dimensione sua confiança nas seguintes organizações e autoridades ao se referirem aos riscos associados à energia nuclear.

\begin{tabular}{lcccccccc}
\multicolumn{3}{c}{ Nenhuma } & \multicolumn{1}{c}{ Total } & Não sei \\
Comissão Nacional de Energia Nuclear & $(1)$ & $(2)$ & $(3)$ & $(4)$ & $(5)$ & $(6)$ & $(7)$ & $($ ) \\
Governo Federal & $(1)$ & $(2)$ & $(3)$ & $(4)$ & $(5)$ & $(6)$ & $(7)$ & $($ ) \\
Governo Municipal & $(1)$ & $(2)$ & $(3)$ & $(4)$ & $(5)$ & $(6)$ & $(7)$ & $($ ) \\
Igreja & $(1)$ & $(2)$ & $(3)$ & $(4)$ & $(5)$ & $(6)$ & $(7)$ & $($ ) \\
Instituto de Pesquisas Energéticas e Nucleares & $(1)$ & $(2)$ & $(3)$ & $(4)$ & $(5)$ & $(6)$ & $(7)$ & $($ ) \\
Lideranças locais & $(1)$ & $(2)$ & $(3)$ & $(4)$ & $(5)$ & $(6)$ & $(7)$ & $($ ) \\
Mídia & $(1)$ & $(2)$ & $(3)$ & $(4)$ & $(5)$ & $(6)$ & $(7)$ & $($ ) \\
Organizações não-governamentais & $(1)$ & $(2)$ & $(3)$ & $(4)$ & $(5)$ & $(6)$ & $(7)$ & $($ ) \\
Políticos & $(1)$ & $(2)$ & $(3)$ & $(4)$ & $(5)$ & $(6)$ & $(7)$ & $($ ) \\
Universidades & $(1)$ & $(2)$ & $(3)$ & $(4)$ & $(5)$ & $(6)$ & $(7)$ & $($ )
\end{tabular}

12. Você acha que as autoridades governamentais omitem informações sobre os riscos potenciais dos rejeitos radioativos?
(1)
(2)
(3)
(4)
(5)
(6)
(7)
( )
Não,
absolutamente
não
absolutamente
sim

13. Você acha que a Comissão Nacional de Energia Nuclear omite informações sobre os riscos potenciais dos rejeitos radioativos?
(1)
(2)
(3)
(4)
(5)
(6)
(7)
( )
Sim, Não sei
não
absolutamente
sim

absolutamente

A questão 14 experimenta o antagonismo, encontrado ser um importante fator na confiança (Sjöberg, 2008). 
14. Em que medida as seguintes autoridades e organizações são contrárias ou favoráveis aos seus interesses?

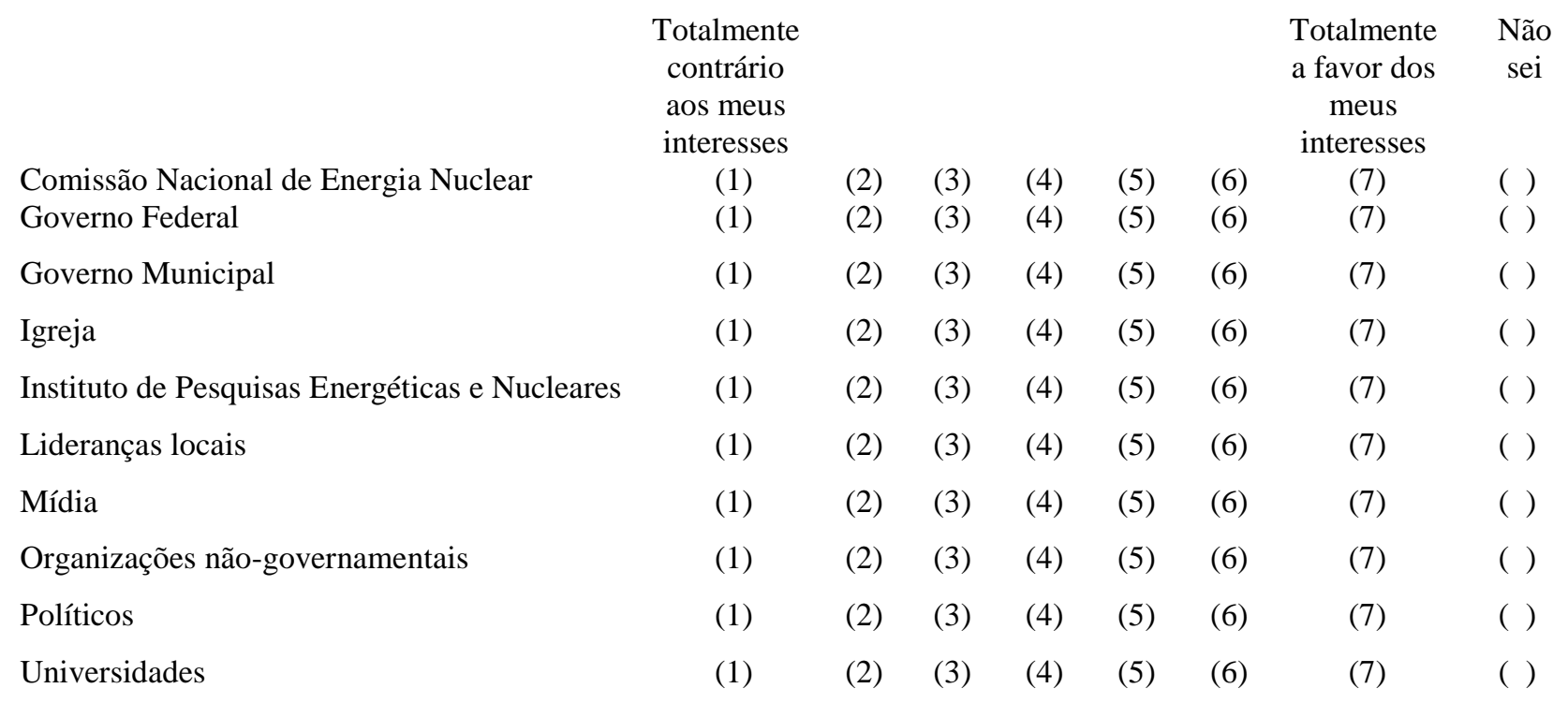

As questões 15 e 16 avaliam a confiança epistêmica, isto é, a confiança na ciência por trás da solução técnica para a gerência e armazenamento de rejeitos radioativos.

15. O conhecimento científico atual é suficientemente confiável para que se possa construir de forma segura um depósito de rejeitos radioativos.

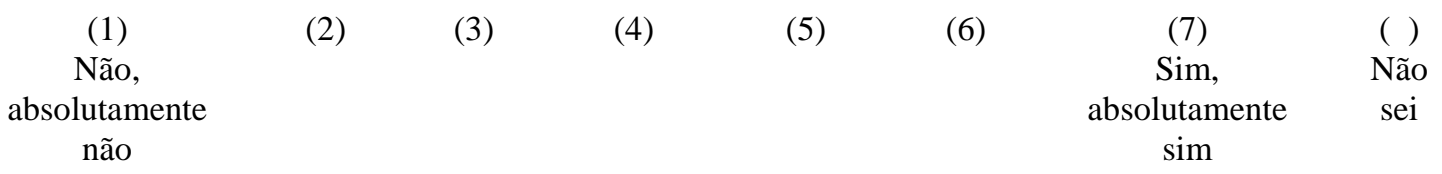

16. As questões técnicas e científicas relacionadas aos rejeitos radioativos estão sendo tratadas de forma satisfatória no Brasil.

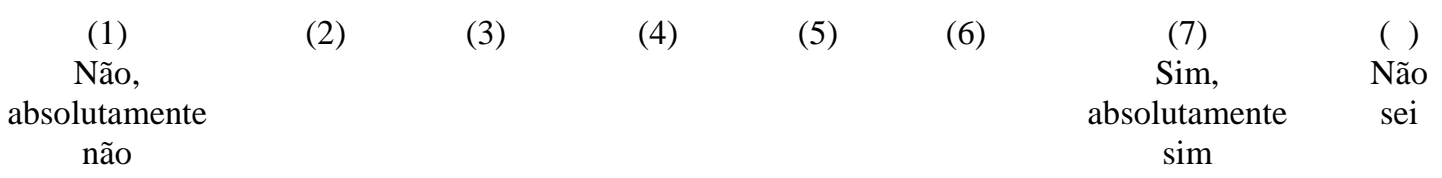

\subsection{Terceiro bloco}

Segundo Touzet et al (2000) a percepção dos riscos não pode ser analisada separadamente da percepção dos benefícios, já que a aceitação de um dado risco está estritamente relacionada aos benefícios esperados da atividade 
que apresenta o risco, seja consciente ou inconscientemente. Tendo isso em vista, as questões 17 e 18 analisam a questão do benefício percebido.

17. Acredita que a energia nuclear traz benefícios para a sociedade?

(1)

Não, absolutamente

não
(2) (3)

(3) (4)

(5)

(6)
(7)

Sim, absolutamente

$\operatorname{sim}$

18. Julgue as seguintes afirmações acerca de um depósito de rejeitos radioativos.

Dentre os benefícios potenciais de um depósito de rejeitos em seu município estariam:

Concordo totalmente
Discordo totalmente

Novos empregos para os moradores do município
(1)

(2)

(3)

(4) (5)

(6)

(7)

Imagem positiva para o município

(1)

(2)

(3)

(4) (5)

(6)

Aumento no otimismo e confiança pela população local

(2)

(3)

(4) (5)

(6)

Empresas de outros setores procurariam o município

(2)

(3)

(4) (5)

(6)

Mais empregos no turismo e outros empreendimentos turísticos

(2)

(3)

(4)

(5)

(6)

Ser reconhecido no sentido positivo

(2)

(3)

(4) (5)

(6)

Possibilidade de consequências positivas atualmente ainda não conhecidas

\author{
(1)
}

(2)

(3)

(4) (5)

(6)

\title{
5.4 Quarto bloco
}

As questões deste bloco analisam (a) voluntariedade das pessoas para enfrentarem os riscos, (b) conhecimento sobre o risco, (c) controlabilidade sobre o risco e (d) severidade das conseqüências. 
19. Quão voluntariamente você se expõe às tecnologias e produtos listados a seguir?

\begin{tabular}{lccccccc} 
& Involuntário & & & & & \multicolumn{2}{c}{ Voluntário } \\
Aditivos em alimentos & $(1)$ & $(2)$ & $(3)$ & $(4)$ & $(5)$ & $(6)$ & $(7)$ \\
Alimentos geneticamente modificados & $(1)$ & $(2)$ & $(3)$ & $(4)$ & $(5)$ & $(6)$ & $(7)$ \\
Antibióticos & $(1)$ & $(2)$ & $(3)$ & $(4)$ & $(5)$ & $(6)$ & $(7)$ \\
Armas de fogo & $(1)$ & $(2)$ & $(3)$ & $(4)$ & $(5)$ & $(6)$ & $(7)$ \\
Bebidas alcoólicas & $(1)$ & $(2)$ & $(3)$ & $(4)$ & $(5)$ & $(6)$ & $(7)$ \\
Cigarro & $(1)$ & $(2)$ & $(3)$ & $(4)$ & $(5)$ & $(6)$ & $(7)$ \\
Eletrodomésticos & $(1)$ & $(2)$ & $(3)$ & $(4)$ & $(5)$ & $(6)$ & $(7)$ \\
Energia eólica & $(1)$ & $(2)$ & $(3)$ & $(4)$ & $(5)$ & $(6)$ & $(7)$ \\
Energia hidroelétrica & $(1)$ & $(2)$ & $(3)$ & $(4)$ & $(5)$ & $(6)$ & $(7)$ \\
Energia nuclear & $(1)$ & $(2)$ & $(3)$ & $(4)$ & $(5)$ & $(6)$ & $(7)$ \\
Energia solar & $(1)$ & $(2)$ & $(3)$ & $(4)$ & $(5)$ & $(6)$ & $(7)$ \\
Internet & $(1)$ & $(2)$ & $(3)$ & $(4)$ & $(5)$ & $(6)$ & $(7)$ \\
Pesticidas & $(1)$ & $(2)$ & $(3)$ & $(4)$ & $(5)$ & $(6)$ & $(7)$ \\
Radiografia médica & $(1)$ & $(2)$ & $(3)$ & $(4)$ & $(5)$ & $(6)$ & $(7)$
\end{tabular}

20. Você acredita que, quando as pessoas são expostas às seguintes tecnologias e produtos, elas possuem conhecimento dos respectivos riscos associados?

Aditivos em alimentos

Alimentos geneticamente modificados

Antibióticos

Armas de fogo

Bebidas alcoólicas

Cigarro

Eletrodomésticos

Energia eólica

Energia hidroelétrica

Energia nuclear

Energia solar

Internet

Pesticidas

Radiografia médica

\section{Desconhecem}

totalmente

(1)

(1)

(1)

(1)

(1)

(1)

(1)

(1)

(1)

(1)

(1)

(1)

(1)

(1)
(2) (3) (4) (5) (6)

(2) (3) (4) (5) (6)

(2) (3) (4) (5) (6)

(2) (3) (4) (5) (6)

(2) (3) (4) (5) (6)

(2) (3) (4) (5) (6)

(2) (3) (4) (5) (6)

(2) (3) (4) (5) (6)

(2) (3) (4) (5) (6)

(2) (3) (4) (5) (6)

(2) (3) (4) (5) (6)

(2) (3) (4) (5) (6)

(2) (3) (4) (5) (6)

(2) (3) (4) (5) (6)
Conhecem totalmente

(7)

(7)

(7)

(7)

(7)

(7)

(7)

(7)

(7)

(7)

(7)

(7)

(7)

(7) 
21. Caso você seja exposto ao risco das tecnologias e produtos listados, em que medida julga conseguir controlá-lo a níveis seguros pra você?

$\begin{array}{lccccccc} & \begin{array}{c}\text { Totalmente } \\ \text { incontrolável }\end{array} & & & & & \begin{array}{c}\text { Totalmente } \\ \text { controlável }\end{array} \\ \text { Aditivos em alimentos } & (1) & (2) & (3) & (4) & (5) & (6) & (7) \\ \text { Alimentos geneticamente modificados } & (1) & (2) & (3) & (4) & (5) & (6) & (7) \\ \text { Antibióticos } & (1) & (2) & (3) & (4) & (5) & (6) & (7) \\ \text { Armas de fogo } & (1) & (2) & (3) & (4) & (5) & (6) & (7) \\ \text { Bebidas alcoólicas } & (1) & (2) & (3) & (4) & (5) & (6) & (7) \\ \text { Cigarro } & (1) & (2) & (3) & (4) & (5) & (6) & (7) \\ \text { Eletrodomésticos } & (1) & (2) & (3) & (4) & (5) & (6) & (7) \\ \text { Energia eólica } & (1) & (2) & (3) & (4) & (5) & (6) & (7) \\ \text { Energia hidroelétrica } & (1) & (2) & (3) & (4) & (5) & (6) & (7) \\ \text { Energia nuclear } & (1) & (2) & (3) & (4) & (5) & (6) & (7) \\ \text { Energia solar } & (1) & (2) & (3) & (4) & (5) & (6) & (7) \\ \text { Internet } & (1) & (2) & (3) & (4) & (5) & (6) & (7) \\ \text { Pesticidas } & (1) & (2) & (3) & (4) & (5) & (6) & (7) \\ \text { Radiografia médica } & (1) & (2) & (3) & (4) & (5) & (6) & (7)\end{array}$

22. Caso aconteça algum acidente envolvendo as tecnologias e produtos listados, quão provável julga que as consequências serão fatais?

Certamente

não serão fatais

Aditivos em alimentos

Alimentos geneticamente modificados

Antibióticos

Armas de fogo

Bebidas alcoólicas

Cigarro

Eletrodomésticos

Energia eólica

Energia hidroelétrica

Energia nuclear

Energia solar

Internet

Pesticidas

Radiografia médica
(1)

(1)

(1)

(1)

(1)

(1)

(1)

(1)

(1)

(1)

(1)

(1)

(1)

(1)
(2) (3) (4) (5) (6)

(2) (3) (4) (5) (6)

(2) (3) (4) (5) (6)

(2) (3) (4) (5) (6)

(2) (3) (4) (5) (6)

(2) (3) (4) (5) (6)

(2) (3) (4) (5) (6)

(2) (3) (4) (5) (6)

(2) (3) (4) (5) (6)

(2) (3) (4) (5) (6)

(2) (3) (4) (5) (6)

(2) (3) (4) (5) (6)

(2) (3) (4) (5) (6)

(2) (3) (4) (5) (6)
Certamente serão fatais

(7)

(7)

(7)

(7)

(7) 


\subsection{Quinto bloco}

As questões 23 e 24 analisam a percepção de riscos que as pessoas possivelmente têm alguma experiência, direta ou indireta, envolvendo aspectos do seu cotidiano, pois é esperada uma percepção realista destes riscos (Sjöberg, 2000a).

23. Entre os itens citados, avalie o risco para você individualmente.

\begin{tabular}{lcccccccc} 
& Muito & & & & \multicolumn{5}{c}{ Muito } & Não sei \\
pequeno & & & & & & \\
Acidente de trânsito & $(1)$ & $(2)$ & $(3)$ & $(4)$ & $(5)$ & $(6)$ & $(7)$ & $($ ) \\
Acidente doméstico & $(1)$ & $(2)$ & $(3)$ & $(4)$ & $(5)$ & $(6)$ & $(7)$ & $($ ) \\
Alcool & $(1)$ & $(2)$ & $(3)$ & $(4)$ & $(5)$ & $(6)$ & $(7)$ & $($ ) \\
Aquecimento global & $(1)$ & $(2)$ & $(3)$ & $(4)$ & $(5)$ & $(6)$ & $(7)$ & $($ ) \\
Alimento geneticamente modificado & $(1)$ & $(2)$ & $(3)$ & $(4)$ & $(5)$ & $(6)$ & $(7)$ & $($ ) \\
Barulho & $(1)$ & $(2)$ & $(3)$ & $(4)$ & $(5)$ & $(6)$ & $(7)$ & $($ ) \\
Catástrofe natural & $(1)$ & $(2)$ & $(3)$ & $(4)$ & $(5)$ & $(6)$ & $(7)$ & $($ ) \\
Cigarro & $(1)$ & $(2)$ & $(3)$ & $(4)$ & $(5)$ & $(6)$ & $(7)$ & $($ ) \\
Contaminação do solo & $(1)$ & $(2)$ & $(3)$ & $(4)$ & $(5)$ & $(6)$ & $(7)$ & $($ ) \\
Dieta inapropriada & $(1)$ & $(2)$ & $(3)$ & $(4)$ & $(5)$ & $(6)$ & $(7)$ & $($ ) \\
Drogas & $(1)$ & $(2)$ & $(3)$ & $(4)$ & $(5)$ & $(6)$ & $(7)$ & $($ ) \\
Incêndio & $(1)$ & $(2)$ & $(3)$ & $(4)$ & $(5)$ & $(6)$ & $(7)$ & $($ ) \\
Indústria química & $(1)$ & $(2)$ & $(3)$ & $(4)$ & $(5)$ & $(6)$ & $(7)$ & $($ ) \\
Obesidade & $(1)$ & $(2)$ & $(3)$ & $(4)$ & $(5)$ & $(6)$ & $(7)$ & $($ ) \\
Poluição do ar & $(1)$ & $(2)$ & $(3)$ & $(4)$ & $(5)$ & $(6)$ & $(7)$ & $($ ) \\
Radiografia médica & $(1)$ & $(2)$ & $(3)$ & $(4)$ & $(5)$ & $(6)$ & $(7)$ & $($ ) \\
Rejeito químico & $(1)$ & $(2)$ & $(3)$ & $(4)$ & $(5)$ & $(6)$ & $(7)$ & $($ ) \\
Rejeito radioativo & $(1)$ & $(2)$ & $(3)$ & $(4)$ & $(5)$ & $(6)$ & $(7)$ & $($ ) \\
Terrorismo & $(1)$ & $(2)$ & $(3)$ & $(4)$ & $(5)$ & $(6)$ & $(7)$ & $($ ) \\
Usina nuclear & $(1)$ & $(2)$ & $(3)$ & $(4)$ & $(5)$ & $(6)$ & $(7)$ & $($ )
\end{tabular}


24. Entre os itens citados, avalie o risco para as pessoas em geral.

\begin{tabular}{|c|c|c|c|c|c|c|c|c|}
\hline Acidente de trânsito & $\begin{array}{c}\text { Muito } \\
\text { pequeno } \\
\text { (1) }\end{array}$ & (2) & (3) & (4) & $(5)$ & (6) & $\begin{array}{l}\text { Muito } \\
\text { grande } \\
\text { (7) }\end{array}$ & $\begin{array}{l}\text { Não sei } \\
\text { ( ) }\end{array}$ \\
\hline Acidente doméstico & (1) & (2) & (3) & (4) & (5) & (6) & (7) & ( ) \\
\hline Alcool & (1) & (2) & (3) & (4) & (5) & (6) & (7) & ( ) \\
\hline Aquecimento global & (1) & (2) & (3) & (4) & $(5)$ & (6) & (7) & ( ) \\
\hline Alimento geneticamente modificado & (1) & (2) & (3) & (4) & $(5)$ & (6) & (7) & ( ) \\
\hline Barulho & (1) & (2) & (3) & (4) & (5) & (6) & (7) & ( ) \\
\hline Catástrofe natural & (1) & (2) & (3) & (4) & $(5)$ & (6) & (7) & ( ) \\
\hline Cigarro & (1) & (2) & (3) & (4) & (5) & (6) & (7) & ( ) \\
\hline Contaminação do solo & (1) & (2) & (3) & (4) & (5) & (6) & (7) & ( ) \\
\hline Dieta inapropriada & (1) & (2) & (3) & (4) & (5) & (6) & (7) & ( ) \\
\hline Drogas & (1) & (2) & (3) & (4) & (5) & (6) & (7) & ( ) \\
\hline Incêndio & (1) & (2) & (3) & (4) & (5) & (6) & (7) & ( ) \\
\hline Indústria química & (1) & (2) & (3) & (4) & (5) & (6) & (7) & ( ) \\
\hline Obesidade & (1) & (2) & (3) & (4) & (5) & (6) & (7) & ( ) \\
\hline Poluição do ar & (1) & (2) & (3) & (4) & (5) & (6) & (7) & ( ) \\
\hline Radiografia médica & (1) & (2) & (3) & (4) & (5) & (6) & (7) & $($ ) \\
\hline Rejeito químico & (1) & (2) & (3) & (4) & $(5)$ & (6) & (7) & ( ) \\
\hline Rejeito radioativo & (1) & (2) & (3) & (4) & (5) & (6) & (7) & ( ) \\
\hline Terrorismo & (1) & (2) & (3) & (4) & (5) & (6) & (7) & ( ) \\
\hline Usina nuclear & (1) & (2) & (3) & (4) & (5) & (6) & (7) & ( ) \\
\hline
\end{tabular}

\subsection{Sexto bloco}

Segundo Sjöberg (2007) as emoções desempenham um papel importante na percepção de risco e atitudes relacionadas. Cada indivíduo reage emocionalmente a ameaças, às vezes fora da proporção com a ameaça real, revelando "reações instintivas" e formando atitudes que dificilmente serão mudadas por meio de informações. Sabe-se que nos processos em que ocorre participação do público, as reações contrárias podem ser amenizadas (Sjöberg, 2003).

Uma melhor informação sobre as reações emocionais pode ser obtida ao se pedir para que o entrevistado responda exatamente ao momento em que ele lê a pergunta. 
25. Julgue rápida e espontaneamente o que você sente em relação aos alimentos geneticamente modificados.

\section{Grau muito}

pequeno

Culpa

Desprezo

Medo

Otimismo

Pessimismo

Preocupação

Raiva

Satisfação

Vergonha
(1)

(1)

(1)

(1)

(1)

(1)

(1)

(1)

(1)
(2)

(2)

(2)

(2)

(2)

(2)

(2)

(2)

(2)
(3)

(3)

(3)

(3)

(3)

(3)

(3)

(3)

(3)

26. Julgue rápida e espontaneamente o que você sente em relação aos terrorismo. Grau muito pequeno

Culpa

(1)

(1)

(1)

Medo

Otimismo

Pessimismo

Preocupação

Raiva

Satisfação

Vergonha
(1)

(1)

(1)

(1)

(1)

(1)
(2)

(2)

(2)

(2)

(2)

(2)

(2)

(2)

(2)
(3)

(3)

(3)

(3)

(3)

(3)

(3)

(3)

(3)

(4)
(4)

(5)

(6)

Grau muito elevado

(7)

(7)

(4) (5)

(6)

(7)

(4) (5) (6)

(7)

(4) (5) (6)

(7)

(4) (5)

(6)

(7)

(7)

(4) (5)

(6)

(7)

(4) (5)

(6)

27. Julgue rápida e espontaneamente o que você sente em relação a um depósito de rejeitos radioativos

\begin{tabular}{|c|c|c|c|c|c|c|c|}
\hline Culpa & $\begin{array}{l}\text { Grau muito } \\
\text { pequeno } \\
\text { (1) }\end{array}$ & (2) & (3) & (4) & (5) & (6) & $\begin{array}{c}\text { Grau muito } \\
\text { elevado } \\
\text { (7) }\end{array}$ \\
\hline Desprezo & (1) & (2) & (3) & (4) & (5) & (6) & (7) \\
\hline Medo & (1) & (2) & (3) & (4) & (5) & (6) & (7) \\
\hline Otimismo & (1) & (2) & (3) & (4) & (5) & (6) & (7) \\
\hline Pessimismo & (1) & (2) & (3) & (4) & (5) & (6) & (7) \\
\hline Preocupação & (1) & (2) & (3) & (4) & (5) & (6) & (7) \\
\hline Raiva & (1) & (2) & (3) & (4) & (5) & (6) & (7) \\
\hline Satisfação & (1) & (2) & (3) & (4) & (5) & (6) & (7) \\
\hline Vergonha & (1) & (2) & (3) & (4) & (5) & (6) & (7) \\
\hline
\end{tabular}


28. Julgue rápida e espontaneamente o que você sente em relação aos rejeitos radioativos.

\begin{tabular}{|c|c|c|c|c|c|c|c|}
\hline Culpa & $\begin{array}{l}\text { Grau muito } \\
\text { pequeno } \\
\text { (1) }\end{array}$ & (2) & (3) & (4) & (5) & (6) & $\begin{array}{c}\text { Grau muito } \\
\text { elevado } \\
\text { (7) }\end{array}$ \\
\hline Desprezo & (1) & (2) & (3) & (4) & (5) & (6) & (7) \\
\hline Medo & (1) & (2) & (3) & (4) & (5) & (6) & (7) \\
\hline Otimismo & (1) & (2) & (3) & (4) & (5) & (6) & (7) \\
\hline Pessimismo & (1) & (2) & (3) & (4) & (5) & (6) & (7) \\
\hline Preocupação & (1) & (2) & (3) & (4) & (5) & (6) & (7) \\
\hline Raiva & (1) & (2) & (3) & (4) & (5) & (6) & (7) \\
\hline Satisfação & (1) & (2) & (3) & (4) & (5) & (6) & (7) \\
\hline Vergonha & (1) & (2) & (3) & (4) & (5) & (6) & (7) \\
\hline
\end{tabular}

29. Julgue rápida e espontaneamente o que você sente em relação a energia solar.

Grau muito Grau muito

$\begin{array}{lccccccc}\text { Culpa } & \text { pequeno } & & & & \text { elevado } \\ \text { Desprezo } & (1) & (2) & (3) & (4) & (5) & (6) & (7) \\ \text { Medo } & (1) & (2) & (3) & (4) & (5) & (6) & (7) \\ \text { Otimismo } & (1) & (2) & (3) & (4) & (5) & (6) & (7) \\ \text { Pessimismo } & (1) & (2) & (3) & (4) & (5) & (6) & (7) \\ \text { Preocupação } & (1) & (2) & (3) & (4) & (5) & (6) & (7) \\ \text { Raiva } & (1) & (2) & (3) & (4) & (5) & (6) & (7) \\ \text { Satisfação } & (1) & (2) & (3) & (4) & (5) & (6) & (7) \\ \text { Vergonha } & (1) & (2) & (3) & (4) & (5) & (6) & (7) \\ & (1) & (2) & (3) & (4) & (5) & (6) & (7)\end{array}$

\subsection{Sétimo bloco}

Sjöberg (2009a) encontrou que o princípio da precaução afeta a percepção de risco e atitudes com respeito ao rejeito radioativo e que as pessoas tendem a exibir um alto nível de concordância com os itens de precaução e rejeitam os itens a favor de correr riscos. 
30. A instalação de um depósito de rejeitos radioativos em seu município deve...

Concordo

totalmente

Ser evitada, a menos que seja provado não oferecer riscos.

Ser aceita, desde que ofereça alguns benefícios.

Ser aceita, caso não haja provas de que é perigoso.

Ser aceita, mesmo que os riscos sejam mínimos.

Ser evitada, independentemente do quão seguro é a informação sobre os riscos.

Ser aceita, se provado oferecer mais benefícios que riscos.

Ser evitada, caso haja uma alternativa à sua construção a custos razoáveis

Ser evitada, até que se saiba mais sobre os riscos.

Ser evitada, a menos que os riscos sejam voluntariamente assumidos pela comunidade

Ser evitada, pois nem a ciência alcançará conhecimento absoluto dos riscos futuros associados.

Ser evitada, caso as pessoas se preocupem com os riscos, mesmo sem terem sido provados.

Ser evitada, a menos que forneça fortes argumentos científicos de que o risco é mínimo.
(1)

(1)

(1)

(1)

(1)

(1)

(1)

(1)

(1)

(1)

(1)

(2)

(3)

(4)

(5)

(6)

(1)

(2)

(3)

(4)

(5)

(6)

(7) iscordo totalmente
(7) क

\subsection{Oitavo bloco}

Destinado a caracterizar o perfil socio econômico e cultural do entrevistado. $\mathrm{Na}$ questão 34, é aconselhável que se efetue a conversão para valores reais da moeda vigente quando da aplicação efetiva do questionário.

\section{Sexo:}

( ) Feminino

( ) Masculino 
32. Idade:
( ) Menos que 16 anos
( ) $16-24$
( ) $25-29$
( ) $30-39$
( ) $40-49$
( ) 50 ou mais

33. Educação (o maior nível de estudo):
( ) Ensino Fundamental incompleto ou completo
( ) Ensino Médio incompleto ou completo
( ) Ensino Superior incompleto ou completo
( ) Pós-graduação

34. Renda (em salários mínimos):
( ) Até 1
( ) De 1 a 2
( ) De 2 a 5
( ) De 5 a 10
( ) Mais que 10 


\section{DISCUSSÃO DOS RESULTADOS}

A partir dos resultados obtidos com esse tipo de questionário aplicado, podem ser realizadas inúmeras análises. Apresenta-se a seguir, a título de ilustração, alguns exemplos de análises que julgamos serem úteis para a compreensão dos processos de percepção de riscos e para o estabelecimento de programas de comunicação com o público. Como já mencionado, este trabalho tem, essencialmente, como objetivo estruturar um questionário para aplicação em possíveis locais candidatos a receber o repositório nacional de rejeitos radioativos de baixa e média atividade. É bastante provável que o local escolhido não esteja localizado em grandes centros urbanos, mas em municípios de pequeno porte em termos de números de habitantes, e nesse caso, o questionário deveria ser testado em locais semelhantes. A aplicação piloto em tais locais poderia induzir os moradores a crer que o seu município estaria sendo efetivamente cogitado a receber um depósito de rejeitos radioativos, podendo assim criar um clima de apreensão na população. Por estas razões, o questionário foi aplicado apenas na cidade de São Paulo para testes de validação.

O questionário foi aplicado numa amostra de 47 indivíduos, aleatoriamente escolhidos. Devido ao tamanho da amostra considerada, os resultados apresentados exibem incertezas grandes em muitos casos, mas dão uma ideia qualitativa razoável daquilo que se esperaria obter numa aplicação real.

Nas análises apresentadas a seguir, introduziu-se a variável "índice", que é a média aritmética dos números atribuídos na escala de resposta, entre todos os respondentes.

\subsection{Das atitudes e aceitabilidade do repositório em seu município}

A Figura 2 apresenta na forma de índice e a Figura 3 em porcentual os entrevistados que manifestaram sentimento negativo em relação a um repositório de rejeitos radioativos e o consideram aceitável. 


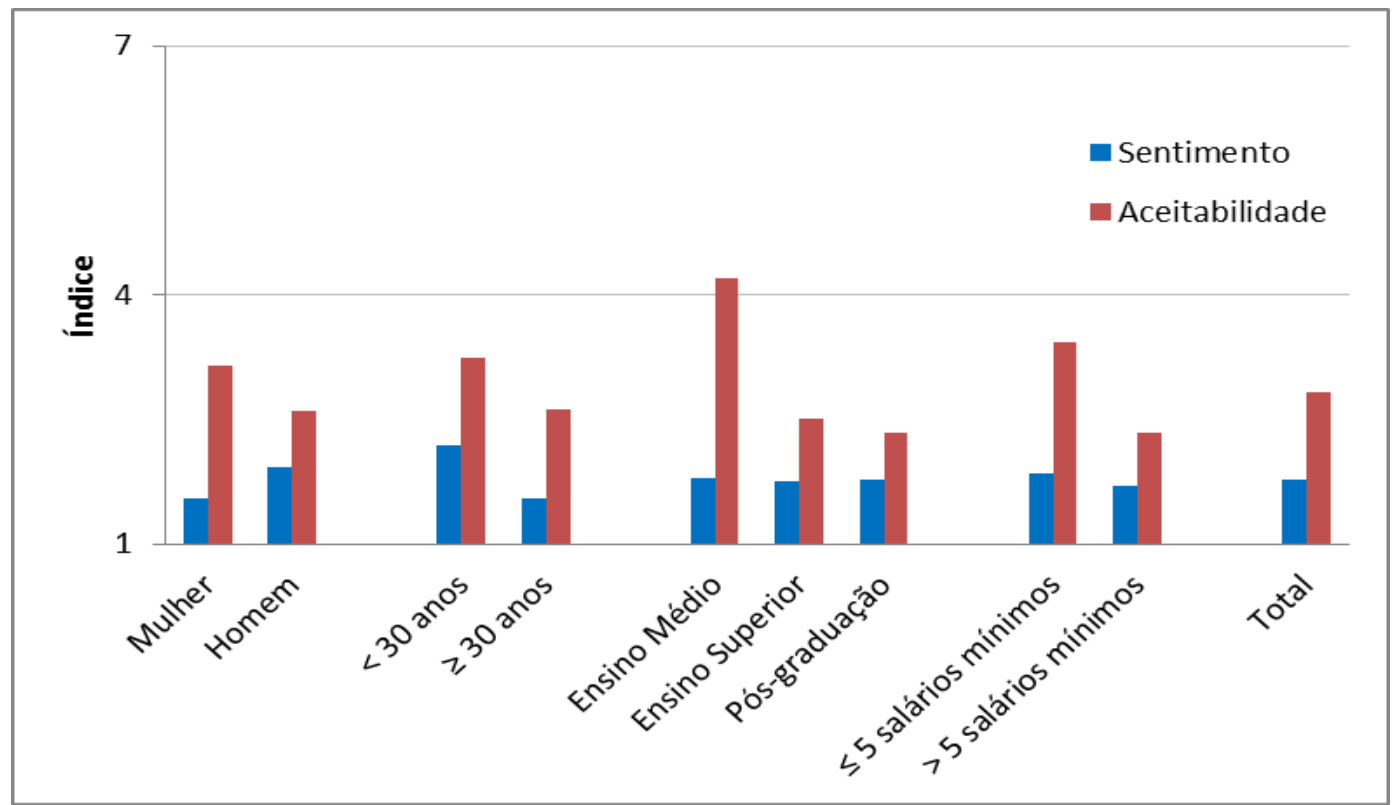

Figura 3 Índices do sentimento (1 para extremamente negativo, 7 para extremamente positivo) e da aceitabilidade (1 para totalmente inaceitável, 7 para totalmente aceitável)

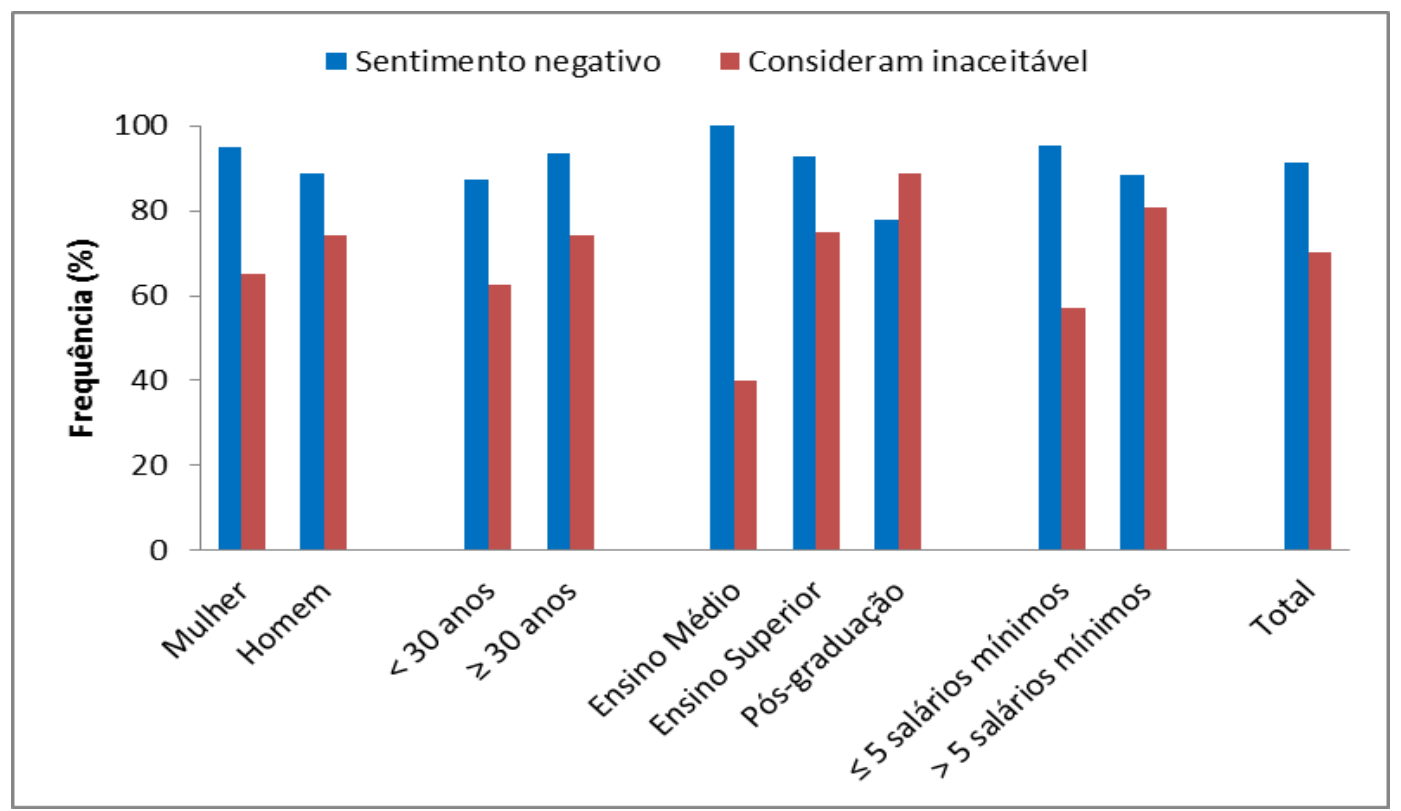

Figura 4 Percentual dos entrevistados que demonstraram sentimento negativo e consideraram o depósito de rejeitos radioativos inaceitável

O percentual dos que manifestaram sentimento negativo foi obtido somando-se os entrevistados que responderam alternativas 1, 2 ou 3, que correspondem ao sentimento negativo para o depósito de rejeitos radioativos. 
A correlação entre o sentimento negativo e aceitabilidade foi relativamente baixa $(0,33)$, mostrando que o fato de se ter uma atitude negativa em relação ao depósito de rejeito radioativo, não implica necessariamente uma rejeição ao repositório. Isso se reflete também nas Figuras 2 e 3 onde observa-se que 0 percentual dos que o consideram inaceitável é menor que o percentual de sentimento negativo (Figura 3), e o índice de aceitabilidade é sempre maior que o sentimento negativo (Figura 2).

\subsection{Dos benefícios}

$\mathrm{Na}$ Figura 4 pode-se perceber a relação entre benefícios do repositório (são aqueles que o respondente concorda como sendo um benefício dentre os possíveis listados) e a aceitabilidade do mesmo. O percentual de benefícios do depósito é a média dos percentuais de respondentes que percebem o benefício. Quanto maior o percentual dos benefícios percebidos do depósito percebidos pelos entrevistados, menor o percentual dos que o consideram inaceitável.

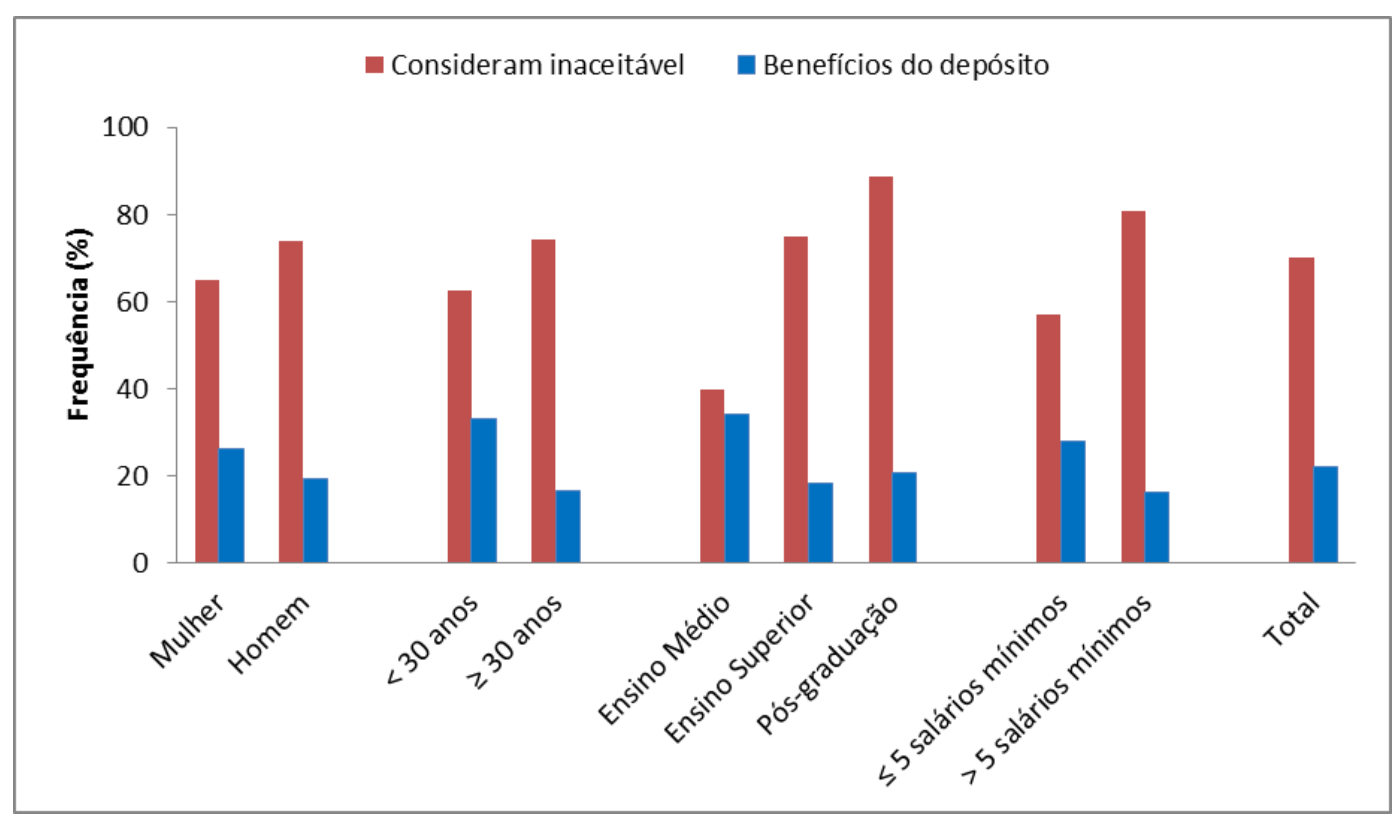

Figura 5 Percentual dos benefícios do depósito e dos que o consideram inaceitável

Os sete benefícios listados (novos empregos, imagem positiva para 0 município, aumento do otimismo e confiança da população local, interesse de 
empresas de outros setores, empregos no ramo turístico, reconhecimento positivo e possibilidade de consequências positivas não conhecidas) mostraram-se consistentes com um alfa de Cronbach de 0,86.

Uma outra forma de se visualizar a importância relativa dos benefícios, seria realizar uma análise de regressão, com atitudes de risco (intenções de avaliar a situação de risco de modo favorável ou não) como variável dependente e benefícios como independente. Esse tipo de análise não foi exemplificada em virtude do tamanho pequeno da amostra disponível neste trabalho.

\subsection{Da comparação com a percepção de outros riscos}

Alguns riscos foram avaliados tanto para uma situação de risco pessoal (para o respondente) como para risco para as pessoas em geral e os valores médios obtidos são apresentados na Figura 5.

É interessante notar que os índices do risco para as pessoas em geral são maiores que os índices do risco pessoal em todos os casos, o que está de acordo com o estudo de Sjöberg (2003a), em que foi solicitado para avaliar 34 perigos em termos de risco em três amostras aleatórias na população sueca. 


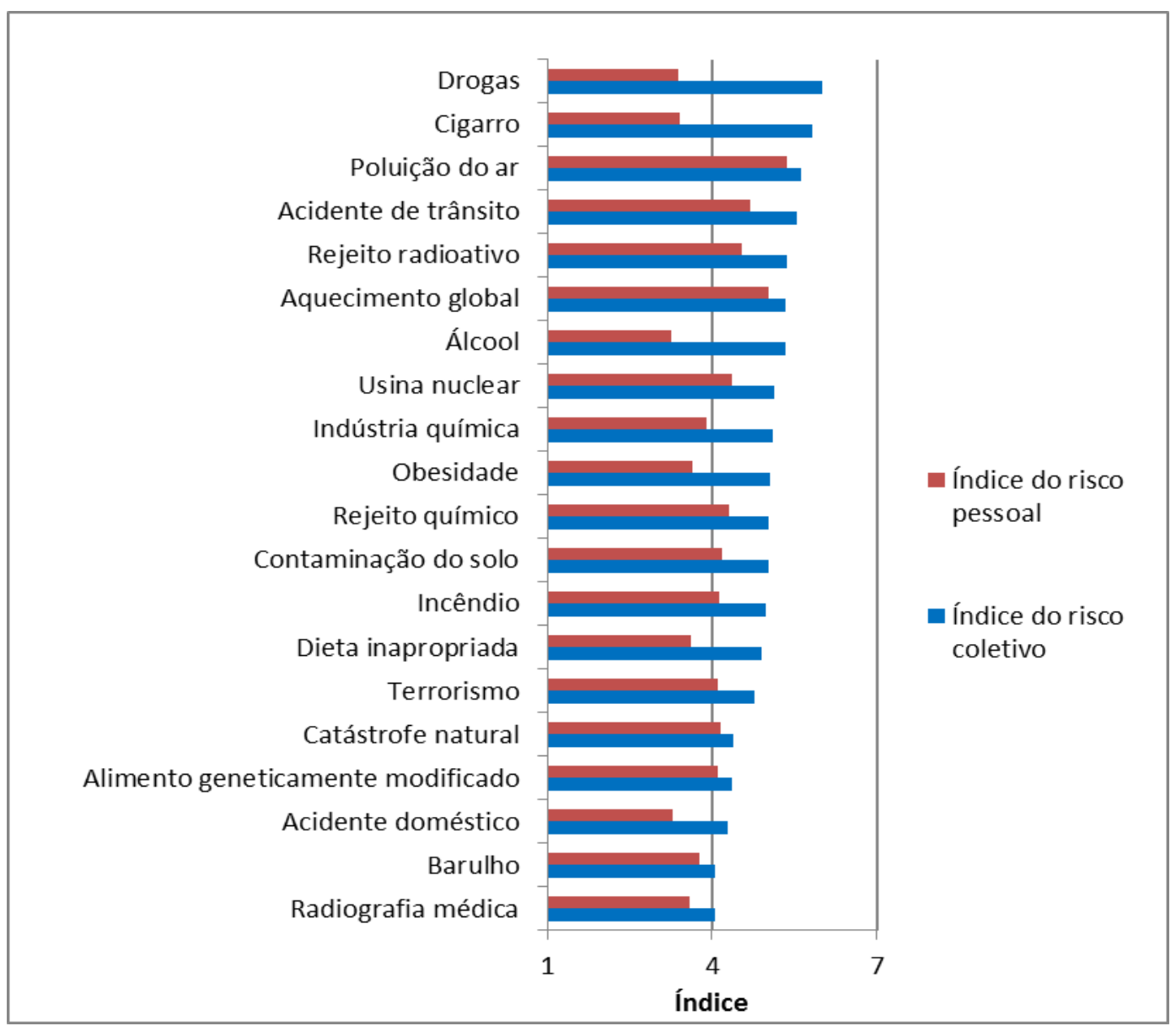

Figura 6 Índices de risco pessoal e coletivo para vários perigos

As diferenças entre o índice de risco para as pessoas em geral e risco pessoal constituem uma medida de negação do risco. E de acordo com Sjöberg (2003), a negação do risco está fortemente relacionada com a possibilidade de proteção, implicando que a diferença entre risco pessoal e coletivo é grande quando as pessoas acreditam que podem facilmente se proteger contra um perigo.

\subsection{Da confiança}

Foi avaliada a confiança na Comissão Nacional de Energia Nuclear, no Governo Federal, no Governo Municipal, na Igreja, no Instituto de Pesquisas Energéticas e Nucleares, em lideranças locais, na mídia, nas organizações não governamentais, nos políticos e nas universidades. 
Na Figura 6 é possível visualizar o quanto os respondentes confiam em cada uma das organizações e autoridades referidas acima.

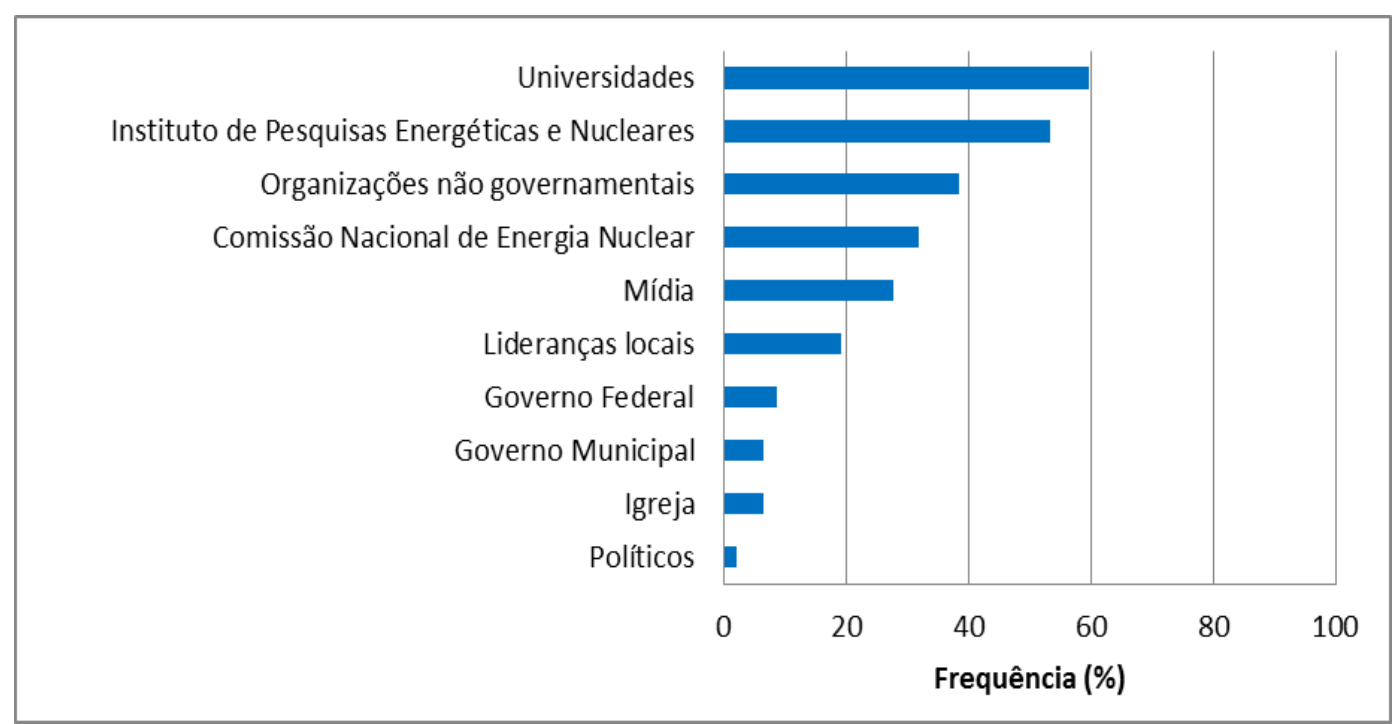

Figura 7 Percentual dos respondentes que confiam nas organizações e autoridades listadas

O gráfico da Figura 7 apresenta o percentual dos entrevistados que confiam nas autoridades governamentais e na Comissão Nacional de Energia Nuclear (CNEN) ao se referir aos riscos associados com a energia nuclear e o percentual dos acreditam que estes omitem informações sobre rejeito radioativo.

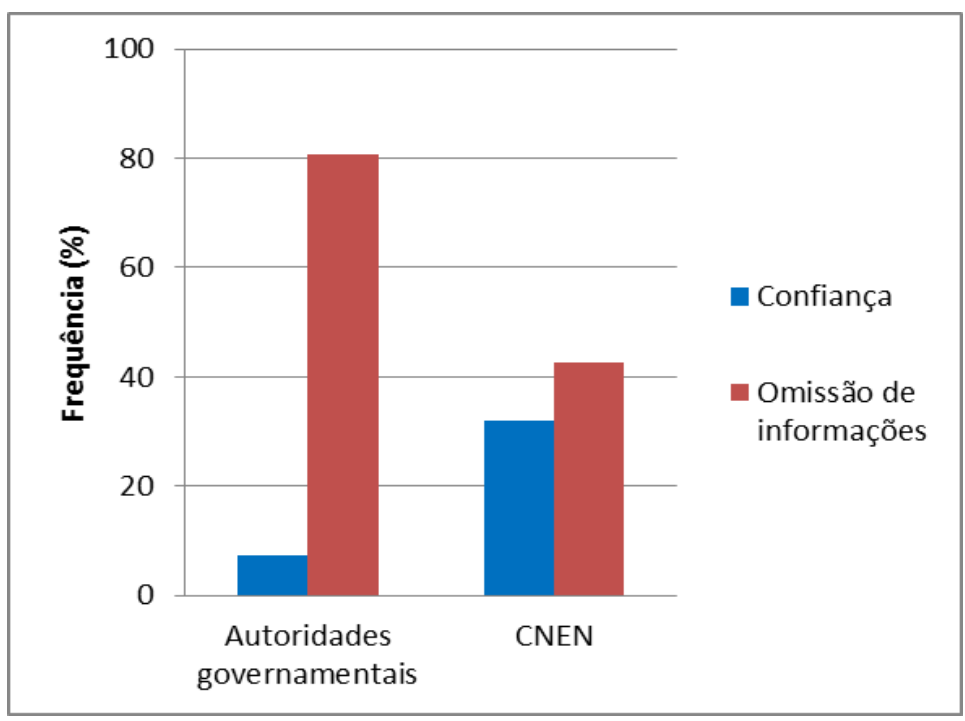

Figura 8 Percentual dos entrevistados que confiam nas autoridades governamentais e na Comissão Nacional de Energia Nuclear (CNEN) 
A fim de esclarecer o papel da confiança social, da confiança epistêmica e do antagonismo nas atitudes e percepção de risco, podemos criar três índices através da fusão das perguntas que avaliaram a percepção dos mesmos, aplicar um modelo de regressão linear simples para atitudes para o repositório e encontrar a percentagem da variância explicada de cada. O mesmo procedimento é interessante ao considerar risco para o município como variável dependente.

\subsection{Do estigma}

As sete alegações que expressam a preocupação referente à instalação de depósito de rejeitos são apresentadas na Tabela 1, junto com a proporção de respondentes que concordam com as afirmações apresentadas. A Tabela 1 apresenta também as correlações entre cada uma das alegações de estigma e atitude para o depósito.

Tabela 1 Concordância com as alegações de estigma e correlações com atitude

\begin{tabular}{|l|c|c|}
\hline Um depósito de rejeitos radioativos em meu município... & $\begin{array}{c}\text { Percentagem } \\
\text { dos que } \\
\text { concordam }\end{array}$ & $\begin{array}{c}\text { Correlação com atitude } \\
\text { em relação ao depósito } \\
\text { de rejeitos radioativos }\end{array}$ \\
\hline Seria uma forte preocupação para os moradores locais & $72 \%$ & 0,43 \\
\hline Traria ao município uma imagem muito ruim & $64 \%$ & 0,48 \\
\hline Faria com que eu votasse em um partido contrário a essa decisão & $60 \%$ & 0,49 \\
\hline Faria-me mudar se tivesse a oportunidade & $51 \%$ & 0,36 \\
\hline Seria vergonhoso & $49 \%$ & 0,49 \\
\hline Conduziria a graves conflitos entre as pessoas & $40 \%$ & 0,25 \\
\hline Faria com que as empresas se mudassem & $36 \%$ & 0,23 \\
\hline
\end{tabular}

Nota-se que a maioria dos respondentes demonstram principalmente incômodo com a possibilidade de se instalar uma imagem ruim do município. Interessante observar o que parece ser uma inconsistência nas respostas, o fato dos respondentes não confiarem nos políticos e afirmarem que estariam dispostos a votar em partidos contrários a construção do repositório; questões adicionais talvez pudessem ser introduzidas no questionário. 


\subsection{Das reações emocionais}

Loewenstein (2001) argumenta que emoções desempenham um papel importante na experiência de risco. Com o intuito de verificar se realmente o é, examina-se várias emoções em relação ao repositório, rejeitos radioativos, terrorismo e alimentos geneticamente modificados. Ao combinar as emoções negativas em um índice e calcular o coeficiente alfa, teremos quão relacionados estão os itens neste índice. Isto também vale para as emoções positivas.

Foram listadas nove emoções, sete das quais eram negativas (culpa, desprezo, medo, pessimismo, preocupação, raiva e vergonha) e duas positivas (otimismo e satisfação). Na questão relativa ao depósito de rejeitos radioativos, foi realizada a análise de consistência interna nos sete itens de emoções negativas e encontrou-se um coeficiente alfa de 0,83 . Para as duas emoções positivas, o valor foi de 0,84 . Na questão relativa ao rejeito radioativo, as emoções apresentaram um coeficiente alfa de 0,81 para as emoções negativas e 0,76 para as positivas. Estes números validam os itens para a medição das emoções negativas e positivas referentes ao depósito e ao rejeito em si, mostrando que o agrupamento é consistente.

$\mathrm{Na}$ Figura 8 são apresentados os índices obtidos para as emoções positivas e negativas. 


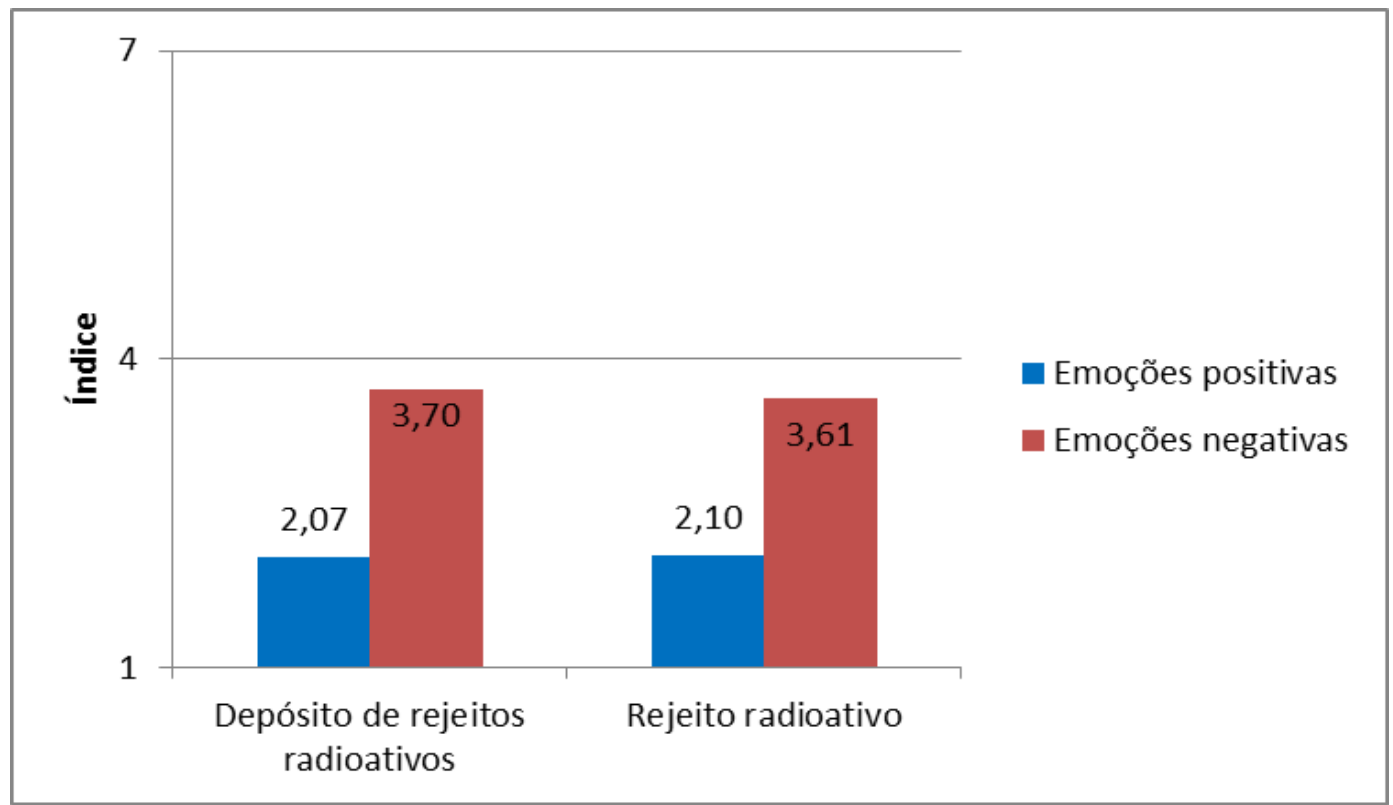

Figura 9 Índices de emoções positivas e negativas para depósito de rejeitos radioativos e rejeito radioativo

Os índices das emoções positivas e negativas são menores do que 4 (posição neutra, nem negativa nem positiva) indicando que os respondentes julgam sentir cada reação emocional em grau pequeno, tanto para o depósito como para o rejeito radioativo.

$\mathrm{Na}$ Tabela 2 são apresentadas as correlações das emoções positivas para um depósito de rejeitos radioativo com as emoções positivas para o rejeito radioativo $(0,80)$, das emoções negativas para um depósito com as emoções negativas para o rejeito $(0,85)$.

As emoções positivas do depósito se correlacionam consideravelmente $(0,50)$ com a atitude para o mesmo, assim como as emoções negativas $(-0,48)$.

As correlações apresentadas mostram o quanto as emoções entre rejeito radioativo e depósito de rejeitos radioativos estão ligadas e o quanto as emoções estão correlacionadas com as atitudes. 
Tabela 2 Correlações entre emoções positivas, emoções negativas e atitude com relação a um depósito de rejeitos radioativos

\begin{tabular}{|l|c|c|c|}
\hline & $\begin{array}{c}\text { Emoções } \\
\text { positivas para o } \\
\text { rejeito radioativo }\end{array}$ & $\begin{array}{c}\text { Emoções } \\
\text { negativas para o } \\
\text { rejeito radioativo }\end{array}$ & $\begin{array}{c}\text { Atitude com relação a } \\
\text { um depósito de rejeitos } \\
\text { radioativos }\end{array}$ \\
\hline $\begin{array}{l}\text { Emoções positivas para um depósito } \\
\text { de rejeitos radioativos }\end{array}$ & 0,80 & $-0,16$ & 0,50 \\
\hline $\begin{array}{l}\text { Emoções negativas para um depósito } \\
\text { de rejeitos radioativos }\end{array}$ & $-0,35$ & 0,85 & $-0,48$ \\
\hline
\end{tabular}

\subsection{Do princípio da precaução}

As alegações acerca do depósito de rejeitos radioativos foram combinadas em dois índices chamados 'aceitar riscos' e 'evitar riscos'. O índice 'aceitar riscos' apresentou um coeficiente alfa de Cronbach de 0,84 e o índice 'evitar riscos', 0,76.

$40 \%$ dos respondentes manifestaram disposição em aceitar os riscos de um depósito de rejeitos radioativos, com a predominância da condicionante 'desde que ofereça alguns benefícios'. Aceitar os riscos com esta condicionante possui uma correlação de 0,65 com a aceitabilidade do depósito. 83 \% quer evitar os riscos, com a predominância da condicionante 'a menos que seja provado não oferecer riscos'.

Tabela 3 Percentual dos que concordam com as alegações acerca do depósito de rejeitos radioativos e correlação destas com aceitabilidade do depósito

\begin{tabular}{|l|c|c|}
\hline $\begin{array}{l}\text { A instalação de um depósito de rejeitos radioativos em seu } \\
\text { município deve... }\end{array}$ & $\begin{array}{c}\text { Percentual } \\
\text { dos que } \\
\text { concordam }\end{array}$ & $\begin{array}{c}\text { Correlação com } \\
\text { aceitabilidade de } \\
\text { um depósito }\end{array}$ \\
\hline Ser aceita, desde que ofereça alguns benefícios. & $40 \%$ & 0,65 \\
\hline Ser aceita, caso não haja provas de que é perigoso. & $36 \%$ & 0,54 \\
\hline Ser aceita, se provado oferecer mais benefícios do que riscos. & $36 \%$ & 0,51 \\
\hline Ser aceita, mesmo que os riscos sejam mínimos. & $9 \%$ & 0,18 \\
\hline Ser evitada, até que se saiba mais sobre os riscos. & $85 \%$ & 0,21 \\
\hline Ser evitada, a menos que seja provado não oferecer riscos. & $83 \%$ & 0,04 \\
\hline $\begin{array}{l}\text { Ser evitada, caso haja um alternativa à sua construção a custos } \\
\text { razoáveis. }\end{array}$ & $74 \%$ & $-0,12$ \\
\hline $\begin{array}{l}\text { Ser evitada, no caso das pessoas se preocuparem com os riscos, } \\
\text { mesmo sem terem sido provados. }\end{array}$ & $60 \%$ & 0,25 \\
\hline $\begin{array}{l}\text { Ser evitada, independentemente do quão seguro é a informação } \\
\text { sobre os riscos. }\end{array}$ & $57 \%$ & 0,25 \\
\hline $\begin{array}{l}\text { Ser evitada, a menos que forneça fortes argumentos científicos de } \\
\text { que o risco é mínimo. }\end{array}$ & $55 \%$ & $-0,02$ \\
\hline $\begin{array}{l}\text { Ser evitada, pois nem a ciência alcançará conhecimento absoluto } \\
\text { dos riscos futuros associados. }\end{array}$ & $53 \%$ & 0,20 \\
\hline $\begin{array}{l}\text { Ser evitada, a menos que os riscos sejam voluntariamente } \\
\text { assumidos pela comunidade. }\end{array}$ & $32 \%$ & 0,04 \\
\hline
\end{tabular}




\subsection{Das correlações mais significativas}

\section{As correlações mais significativas obtidas foram as seguintes:}

- Para a atitude negativa (sendo avaliada pelo sentimento negativo):

\begin{tabular}{|l|c|}
\hline & $\begin{array}{c}\text { Correlação } \\
\text { com atitude } \\
\text { negativa }\end{array}$ \\
\hline Mais empregos no turismo e outros empreendimentos turísticos & $-0,71$ \\
\hline Riscos a saúde humana & 0,71 \\
\hline Riscos para o município & 0,67 \\
\hline Riscos para o respondente & 0,64 \\
\hline $\begin{array}{l}\text { Omissão por parte das autoridades governamentais sobre informações dos riscos } \\
\text { potenciais do rejeito radioativo }\end{array}$ & 0,60 \\
\hline O município ficaria com uma imagem ruim & 0,54 \\
\hline Satisfação com relação aos rejeitos radioativos & $-0,54$ \\
\hline $\begin{array}{l}\text { (a instalação de um depósito de rejeitos radioativos deve) Ser evitada, } \\
\text { independentemente do quão seguro é a informação sobre os riscos. }\end{array}$ & 0,54 \\
\hline $\begin{array}{l}\text { (a instalação de um depósito de rejeitos radioativos deve) Ser evitada, até que se } \\
\text { saiba mais sobre os riscos. }\end{array}$ & 0,54 \\
\hline
\end{tabular}

\section{- Risco para o município:}

\begin{tabular}{|l|c|}
\hline & $\begin{array}{c}\text { Correlação } \\
\text { com risco } \\
\text { para o } \\
\text { município }\end{array}$ \\
\hline Riscos para o respondente & 0,85 \\
\hline $\begin{array}{l}\text { Omissão por parte das autoridades governamentais sobre informações dos riscos } \\
\text { potenciais do rejeito radioativo }\end{array}$ & 0,71 \\
\hline O município ficaria com uma imagem ruim & 0,52 \\
\hline Mais empregos no turismo e outros empreendimentos turísticos & $-0,51$ \\
\hline Satisfação com relação aos rejeitos radioativos & $-0,50$ \\
\hline $\begin{array}{l}\text { (a instalação de um depósito de rejeitos radioativos deve) Ser evitada, até que se } \\
\text { saiba mais sobre os riscos. }\end{array}$ & 0,49 \\
\hline Aceitabilidade do depósito de rejeito radioativo & $-0,47$ \\
\hline $\begin{array}{l}\text { (a instalação de um depósito de rejeitos radioativos deve) Ser evitada, } \\
\text { independentemente do quão seguro é a informação sobre os riscos. }\end{array}$ & 0,45 \\
\hline
\end{tabular}


- Risco para o respondente:

\begin{tabular}{|l|c|}
\hline & $\begin{array}{c}\text { Correlação } \\
\text { com risco } \\
\text { para o } \\
\text { respondente }\end{array}$ \\
\hline $\begin{array}{l}\text { Omissão por parte das autoridades governamentais sobre informações dos riscos } \\
\text { potenciais do rejeito radioativo }\end{array}$ & 0,61 \\
\hline Satisfação com relação aos rejeitos radioativos & $-0,51$ \\
\hline O município ficaria com uma imagem ruim & 0,49 \\
\hline $\begin{array}{l}\text { (a instalação de um depósito de rejeitos radioativos deve) Ser evitada, } \\
\text { independentemente do quão seguro é a informação sobre os riscos. }\end{array}$ & 0,47 \\
\hline Aceitabilidade do depósito de rejeito radioativo & $-0,45$ \\
\hline Mais empregos no turismo e outros empreendimentos turísticos & $-0,43$ \\
\hline $\begin{array}{l}\text { (a instalação de um depósito de rejeitos radioativos deve) Ser evitada, até que se } \\
\text { saiba mais sobre os riscos. }\end{array}$ & 0,34 \\
\hline
\end{tabular}




\section{CONCLUSÃO}

O questionário foi elaborado de acordo com a proposta deste trabalho e os dados coletados na sua aplicação piloto, embora restrita a uma amostra pequena de respondentes, indicam que ele pode ser utilizado com confiabilidade em uma pesquisa de opinião para identificar a percepção de risco relativa a rejeitos radioativos.

Vale ressaltar que são inúmeros os temas possíveis de serem abordados no questionário e este trabalho se ateve àqueles que julgamos serem os mais úteis no auxilio ao estabelecimento de programas de comunicação com o público.

O questionário proposto é suficientemente flexível em sua estrutura, de modo a permitir a introdução de novas questões dentro dos temas pois, em uma aplicação em caso real, os municípios candidatos a receber o depósito de rejeitos podem ter características peculiares, somente possíveis de serem identificadas quando esse locais forem de fato apontados pelas autoridades competentes. 


\section{APÊNDICE A - Questionário para estudo de percepção de riscos tecnológicos}

1. Como se sentiria em relação a um depósito de rejeitos radioativos localizado em seu município?

(1)

Extremamente

negativo
(2)

(3)

(4)

(5)

(6)

Extremamente positivo

2. Se um depósito viesse a ser localizado em seu município, qual seria seu grau de envolvimento com a questão?

(1)

Completamente

não envolvido
(2)

(3)

(4)

(5)

(6)

Completamente envolvido

3. Acha que um depósito de rejeitos radioativos traria algum tipo de risco para o município?

\section{(1)}

Não, absolutamente

não
$(2)$

(3)

(4)

(5)

(6)

Sim, absolutamente

sim

4. Acha que um depósito de rejeitos radioativos traria algum tipo de risco para você?

(1)

Não, absolutamente

não
(2)

(3)

(4)

(5)

(6)
(7)

Sim, absolutamente

5. Acredita que seria capaz de proteger-se contra um possível acidente no depósito?

(1)

Não, absolutamente

não
(2)

(3)

(4)

(5)

(6)

Sim, absolutamente sim

6. Acredita que os moradores de seu município seriam capazes de se proteger contra um possível acidente no depósito?

(1)

Não, absolutamente não
(2)

(3)
(4)

(5)

(6)

absolutamente 
7. Considerando a aceitação de um depósito em seu município, julgue as seguintes afirmações.

\begin{tabular}{|c|c|c|c|c|c|c|c|}
\hline \multirow{2}{*}{$\begin{array}{l}\text { O país seria beneficiado com a } \\
\text { construção do depósito em } \\
\text { município. }\end{array}$} & \multicolumn{2}{|c|}{$\begin{array}{l}\text { Não, } \\
\text { lutamente } \\
\text { não }\end{array}$} & & & & \multicolumn{2}{|c|}{$\begin{array}{l}\text { Sim, } \\
\text { absolutamente } \\
\text { sim }\end{array}$} \\
\hline & (1) & (2) & (3) & (4) & (5) & (6) & (7) \\
\hline $\begin{array}{l}\text { O depósito traria benefícios econômicos } \\
\text { ao município. }\end{array}$ & (1) & (2) & (3) & (4) & $(5)$ & (6) & (7) \\
\hline $\begin{array}{l}\text { Um depósito traria espírito de otimismo } \\
\text { para o município. }\end{array}$ & (1) & (2) & (3) & (4) & $(5)$ & (6) & (7) \\
\hline $\begin{array}{l}\text { Empresas de outros setores poderiam se } \\
\text { instalar em seu município. }\end{array}$ & (1) & (2) & (3) & (4) & $(5)$ & (6) & (7) \\
\hline orgulho para o município. & (1) & (2) & (3) & (4) & (5) & (6) & (7) \\
\hline
\end{tabular}

8. Considerando a oposição de um depósito em seu município, julgue as seguintes afirmações.

Sim, absolutamen

te $\operatorname{sim}$

Um depósito traria riscos à saúde humana.

O município ficaria com uma imagem ruim.

Muitas pessoas se mudariam para outras localidades.

Muitas empresas deixariam o município.
(1)

(2)

(1)

(2)

(1)

(2)

(3)

(4)

(5) (6)

(7)

(1)

(2)

(4)

(4)

(5)

(6)

(7)

(6)

(7)

(4)

(5)

(6)

(7) absolutamente não

9. Acha que um depósito de rejeitos radioativos pode fazer mal à saúde dos moradores locais?

(1)

Não, absolutamente

não
(2)

(3)

(4)

(5) 
10. Julgue as declarações abaixo referentes a um depósito de rejeitos radioativos em seu município.

Um depósito de rejeitos radioativos em meu município...

\begin{tabular}{|c|c|c|c|c|c|c|c|}
\hline Seria totalmente inaceitável. & $\begin{array}{l}\text { Concordo } \\
\text { totalmente } \\
\text { (1) }\end{array}$ & (2) & (3) & (4) & (5) & (6) & $\begin{array}{c}\text { Discordo } \\
\text { totalmente } \\
\text { (7) }\end{array}$ \\
\hline Seria vergonhoso. & (1) & (2) & (3) & (4) & (5) & (6) & (7) \\
\hline $\begin{array}{l}\text { Traria ao município uma imagem muito } \\
\text { ruim. }\end{array}$ & (1) & (2) & (3) & (4) & (5) & (6) & (7) \\
\hline Faria com que as empresas se mudassem. & (1) & (2) & (3) & (4) & (5) & (6) & (7) \\
\hline $\begin{array}{l}\text { Conduziria a graves conflitos entre as } \\
\text { pessoas. } \\
\text { Seria uma forte preocupação para os } \\
\text { moradores locais. }\end{array}$ & (1) & (2) & (3) & (4) & (5) & (6) & $\begin{array}{l}\text { (7) } \\
\text { (7) }\end{array}$ \\
\hline Faria-me mudar se tivesse a oportunidade. & (1) & (2) & (3) & (4) & (5) & (6) & (7) \\
\hline $\begin{array}{l}\text { Faria com que eu votasse em um partido } \\
\text { contrário a essa decisão. }\end{array}$ & (1) & (2) & (3) & (4) & (5) & (6) & (7) \\
\hline
\end{tabular}

11. Dimensione sua confiança nas seguintes organizações e autoridades ao se referirem aos riscos associados à energia nuclear.

\begin{tabular}{lcccccccc}
\multicolumn{3}{c}{ Nenhuma } & \multicolumn{1}{c}{ Total } & Não sei \\
Comissão Nacional de Energia Nuclear & $(1)$ & $(2)$ & $(3)$ & $(4)$ & $(5)$ & $(6)$ & $(7)$ & $($ ) \\
Governo Federal & $(1)$ & $(2)$ & $(3)$ & $(4)$ & $(5)$ & $(6)$ & $(7)$ & $($ ) \\
Governo Municipal & $(1)$ & $(2)$ & $(3)$ & $(4)$ & $(5)$ & $(6)$ & $(7)$ & $($ ) \\
Igreja & $(1)$ & $(2)$ & $(3)$ & $(4)$ & $(5)$ & $(6)$ & $(7)$ & $($ ) \\
Instituto de Pesquisas Energéticas e Nucleares & $(1)$ & $(2)$ & $(3)$ & $(4)$ & $(5)$ & $(6)$ & $(7)$ & $($ ) \\
Lideranças locais & $(1)$ & $(2)$ & $(3)$ & $(4)$ & $(5)$ & $(6)$ & $(7)$ & $($ ) \\
Mídia & $(1)$ & $(2)$ & $(3)$ & $(4)$ & $(5)$ & $(6)$ & $(7)$ & $($ ) \\
Organizações não-governamentais & $(1)$ & $(2)$ & $(3)$ & $(4)$ & $(5)$ & $(6)$ & $(7)$ & $($ ) \\
Políticos & $(1)$ & $(2)$ & $(3)$ & $(4)$ & $(5)$ & $(6)$ & $(7)$ & $($ ) \\
Universidades & $(1)$ & $(2)$ & $(3)$ & $(4)$ & $(5)$ & $(6)$ & $(7)$ & $($ )
\end{tabular}

12. Você acha que as autoridades governamentais omitem informações sobre os riscos potenciais dos rejeitos radioativos?

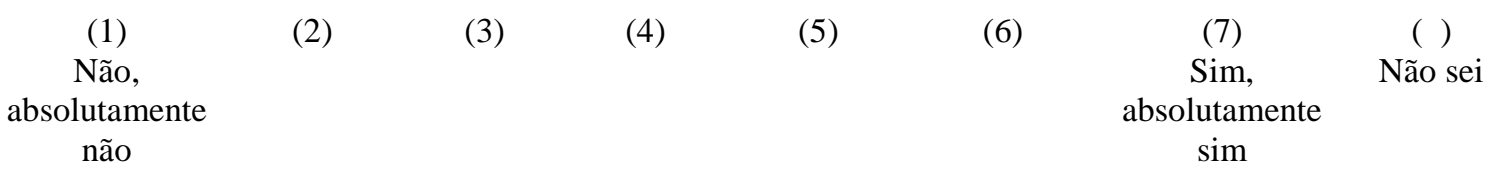


13. Você acha que a CNEN omite informações sobre os riscos potenciais dos rejeitos radioativos?
(1)
(2)
(3)
(4)
(5)
(6)
(7)
( )
Sim, Não sei
não
absolutamente
$\operatorname{sim}$

absolutamente

14. Em que medida as seguintes autoridades e organizações são contrárias ou favoráveis aos seus interesses?

\begin{tabular}{|c|c|c|c|c|c|c|c|}
\hline $\begin{array}{l}\text { Comissão Nacional de Energia Nuclear } \\
\text { Governo Federal }\end{array}$ & $\begin{array}{l}\text { Totalmente } \\
\text { contrário } \\
\text { aos meus } \\
\text { interesses } \\
\text { (1) } \\
(1)\end{array}$ & $\begin{array}{l}(2) \\
(2)\end{array}$ & $\begin{array}{l}\text { (3) } \\
\text { (3) }\end{array}$ & $\begin{array}{l}\text { (4) } \\
\text { (4) }\end{array}$ & $\begin{array}{l}(5) \\
(5)\end{array}$ & $\begin{array}{l}(6) \\
(6)\end{array}$ & $\begin{array}{c}\text { Totalmente } \\
\text { a favor dos } \\
\text { meus } \\
\text { interesses } \\
\text { (7) } \\
\text { (7) }\end{array}$ \\
\hline Governo Municipal & (1) & (2) & (3) & (4) & (5) & (6) & (7) \\
\hline Igreja & (1) & $(2)$ & (3) & (4) & (5) & (6) & (7) \\
\hline Instituto de Pesquisas Energéticas e Nucleares & (1) & (2) & (3) & (4) & (5) & (6) & (7) \\
\hline Lideranças locais & (1) & $(2)$ & (3) & (4) & (5) & (6) & (7) \\
\hline Mídia & (1) & (2) & (3) & (4) & (5) & (6) & (7) \\
\hline Organizações não-governamentais & (1) & (2) & (3) & (4) & (5) & (6) & (7) \\
\hline Políticos & (1) & (2) & (3) & (4) & (5) & (6) & (7) \\
\hline Universidades & (1) & (2) & (3) & (4) & (5) & (6) & (7) \\
\hline
\end{tabular}

15. O conhecimento científico atual é suficientemente confiável para que se possa construir de forma segura um depósito de rejeitos radioativos.

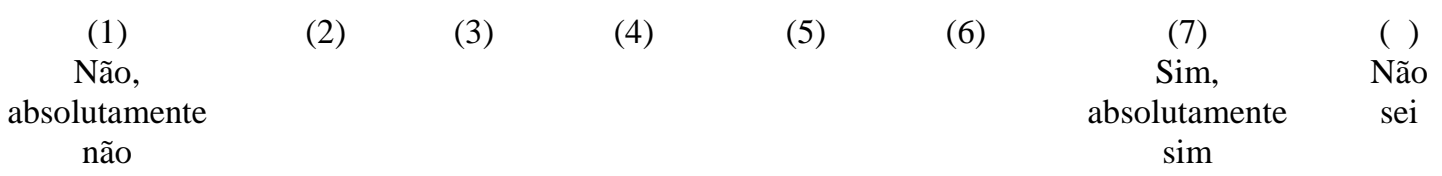

16. As questões técnicas e científicas relacionadas aos rejeitos radioativos estão sendo tratadas de forma satisfatória no Brasil.

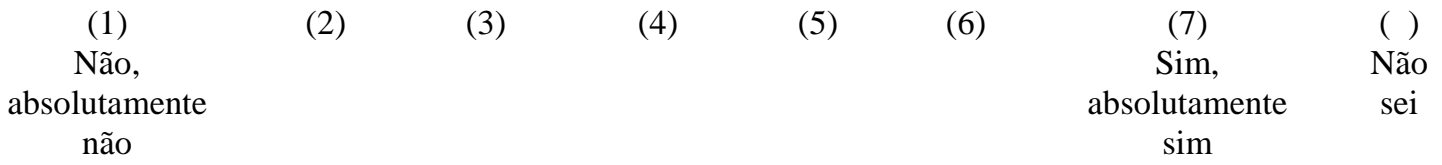


17. Acredita que a energia nuclear traz benefícios para a sociedade?

(1)

Não, absolutamente

não
(2)

(3)

(4)

(5)

$(6)$
(7)

Sim, absolutamente

$\operatorname{sim}$

18. Julgue as seguintes afirmações acerca de um depósito de rejeitos radioativos.

Dentre os benefícios potenciais de um depósito de rejeitos em seu município estariam:

Concordo

totalmente
Discordo

totalmente

Novos empregos para os moradores do município

Imagem positiva para o município

(1)

(1)

(1)

(2)

(3)

(4) (5)

(6)

(7)

Empresas de outros setores procurariam o município

(1)

(2)

(3)

(4) (5) (6)

(7)

Mais empregos no turismo e outros empreendimentos turísticos

$$
\text { (2) }
$$

(3)

(4) (5) (6)

(7)

Ser reconhecido no sentido positivo

(2)

(3)

(4)

(5)

(6)

Possibilidade de consequências positivas atualmente ainda não conhecidas $\begin{array}{llllll}(1) & (2) & \text { (3) (4) (5) (6) }\end{array}$ 
19. Quão voluntariamente você se expõe às tecnologias e produtos listados a seguir?

\begin{tabular}{lccccccc} 
& Involuntário & & & & & \multicolumn{2}{c}{ Voluntário } \\
Aditivos em alimentos & $(1)$ & $(2)$ & $(3)$ & $(4)$ & $(5)$ & $(6)$ & $(7)$ \\
Alimentos geneticamente modificados & $(1)$ & $(2)$ & $(3)$ & $(4)$ & $(5)$ & $(6)$ & $(7)$ \\
Antibióticos & $(1)$ & $(2)$ & $(3)$ & $(4)$ & $(5)$ & $(6)$ & $(7)$ \\
Armas de fogo & $(1)$ & $(2)$ & $(3)$ & $(4)$ & $(5)$ & $(6)$ & $(7)$ \\
Bebidas alcoólicas & $(1)$ & $(2)$ & $(3)$ & $(4)$ & $(5)$ & $(6)$ & $(7)$ \\
Cigarro & $(1)$ & $(2)$ & $(3)$ & $(4)$ & $(5)$ & $(6)$ & $(7)$ \\
Eletrodomésticos & $(1)$ & $(2)$ & $(3)$ & $(4)$ & $(5)$ & $(6)$ & $(7)$ \\
Energia eólica & $(1)$ & $(2)$ & $(3)$ & $(4)$ & $(5)$ & $(6)$ & $(7)$ \\
Energia hidroelétrica & $(1)$ & $(2)$ & $(3)$ & $(4)$ & $(5)$ & $(6)$ & $(7)$ \\
Energia nuclear & $(1)$ & $(2)$ & $(3)$ & $(4)$ & $(5)$ & $(6)$ & $(7)$ \\
Energia solar & $(1)$ & $(2)$ & $(3)$ & $(4)$ & $(5)$ & $(6)$ & $(7)$ \\
Internet & $(1)$ & $(2)$ & $(3)$ & $(4)$ & $(5)$ & $(6)$ & $(7)$ \\
Pesticidas & $(1)$ & $(2)$ & $(3)$ & $(4)$ & $(5)$ & $(6)$ & $(7)$ \\
Radiografia médica & $(1)$ & $(2)$ & $(3)$ & $(4)$ & $(5)$ & $(6)$ & $(7)$
\end{tabular}

20. Você acredita que, quando as pessoas são expostas às seguintes tecnologias e produtos, elas possuem conhecimento dos respectivos riscos associados?

Aditivos em alimentos

Alimentos geneticamente modificados

Antibióticos

Armas de fogo

Bebidas alcoólicas

Cigarro

Eletrodomésticos

Energia eólica

Energia hidroelétrica

Energia nuclear

Energia solar

Internet

Pesticidas

Radiografia médica

\section{Desconhecem}

totalmente

(1)

(1)

(1)

(1)

(1)

(1)

(1)

(1)

(1)

(1)

(1)

(1)

(1)

(1)
(2) (3) (4) (5) (6)

(2) (3) (4) (5) (6)

(2) (3) (4) (5) (6)

(2) (3) (4) (5) (6)

(2) (3) (4) (5) (6)

(2) (3) (4) (5) (6)

(2) (3) (4) (5) (6)

(2) (3) (4) (5) (6)

(2) (3) (4) (5) (6)

(2) (3) (4) (5) (6)

(2) (3) (4) (5) (6)

(2) (3) (4) (5) (6)

(2) (3) (4) (5) (6)

(2) (3) (4) (5) (6)
Conhecem totalmente

(7)

(7)

(7)

(7)

(7)

(7)

(7)

(7)

(7)

(7)

(7)

(7)

(7)

(7) 
21. Caso você seja exposto ao risco das tecnologias e produtos listados, em que medida julga conseguir controlá-lo a níveis seguros pra você?

\begin{tabular}{|c|c|c|c|c|c|c|c|}
\hline Aditivos em alimentos & $\begin{array}{l}\text { Totalmente } \\
\text { incontrolável } \\
\text { (1) }\end{array}$ & (2) & (3) & (4) & (5) & (6) & $\begin{array}{l}\text { Totalmente } \\
\text { controlável } \\
\text { (7) }\end{array}$ \\
\hline Alimentos geneticamente modificados & (1) & (2) & (3) & (4) & (5) & (6) & (7) \\
\hline Antibióticos & (1) & (2) & (3) & (4) & (5) & (6) & (7) \\
\hline Armas de fogo & (1) & (2) & (3) & (4) & (5) & (6) & (7) \\
\hline Bebidas alcoólicas & (1) & (2) & (3) & (4) & (5) & (6) & (7) \\
\hline Cigarro & (1) & (2) & (3) & (4) & (5) & (6) & (7) \\
\hline Eletrodomésticos & (1) & (2) & (3) & (4) & (5) & (6) & (7) \\
\hline Energia eólica & (1) & (2) & (3) & (4) & (5) & (6) & (7) \\
\hline Energia hidroelétrica & (1) & (2) & (3) & (4) & (5) & (6) & (7) \\
\hline Energia nuclear & (1) & (2) & (3) & (4) & (5) & (6) & (7) \\
\hline Energia solar & (1) & (2) & (3) & (4) & (5) & (6) & (7) \\
\hline Internet & (1) & (2) & (3) & (4) & (5) & (6) & (7) \\
\hline Pesticidas & (1) & (2) & (3) & (4) & (5) & (6) & (7) \\
\hline Radiografia médica & (1) & (2) & (3) & (4) & (5) & (6) & (7) \\
\hline
\end{tabular}

22. Caso aconteça algum acidente envolvendo as tecnologias e produtos listados, quão provável julga que as consequências serão fatais?

Certamente não serão fatais

Aditivos em alimentos

Alimentos geneticamente modificados

Antibióticos

Armas de fogo

Bebidas alcoólicas

Cigarro

Eletrodomésticos

Energia eólica

Energia hidroelétrica

Energia nuclear

Energia solar

Internet

Pesticidas

Radiografia médica
(1)

(1)

(1)

(1)

(1)

(1)

(1)

(1)

(1)

(1)

(1)

(1)

(1)

(1)
(2)

(2) (3)

(4)

(5) (6)

Certamente serão fatais

(7)

(2) (3) (4) (5) (6)

(7)

(2) (3) (4) (5) (6)

(7)

(2) (3) (4) (5) (6)

(7)

(2) (3) (4) (5) (6)

(7)

$\begin{array}{llll}\text { (2) (3) (4) (5) (6) } & \end{array}$

(7)

(2) (3) (4) (5) (6)

(7)

(2) (3) (4) (5) (6)

(7)

(2) (3) (4) (5) (6)

(7)

(2) (3) (4) (5) (6)

(7)

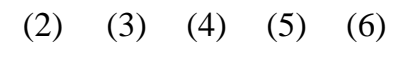

(7)

(2) (3) (4) (5) (6)

(7)

(2) (3) (4) (5) (6)

(7) 
23. Entre os itens citados, avalie o risco para você individualmente.

\begin{tabular}{|c|c|c|c|c|c|c|c|c|}
\hline Acidente de trânsito & $\begin{array}{l}\text { Muito } \\
\text { pequeno } \\
\text { (1) }\end{array}$ & (2) & (3) & (4) & $(5)$ & $(6)$ & $\begin{array}{l}\text { Muito } \\
\text { grande } \\
\text { (7) }\end{array}$ & $\begin{array}{l}\text { Não sei } \\
\text { ( ) }\end{array}$ \\
\hline Acidente doméstico & (1) & (2) & (3) & (4) & $(5)$ & (6) & (7) & ( ) \\
\hline Alcool & (1) & (2) & (3) & (4) & $(5)$ & $(6)$ & (7) & ( ) \\
\hline Aquecimento global & (1) & (2) & (3) & (4) & $(5)$ & (6) & (7) & ( ) \\
\hline Alimento geneticamente modificado & (1) & (2) & (3) & (4) & $(5)$ & (6) & (7) & ( ) \\
\hline Barulho & (1) & (2) & (3) & (4) & $(5)$ & (6) & (7) & $($ ) \\
\hline Catástrofe natural & (1) & (2) & (3) & (4) & $(5)$ & (6) & (7) & ( ) \\
\hline Cigarro & (1) & (2) & (3) & (4) & $(5)$ & (6) & (7) & ( ) \\
\hline Contaminação do solo & (1) & (2) & (3) & (4) & $(5)$ & (6) & (7) & ( ) \\
\hline Dieta inapropriada & (1) & (2) & (3) & (4) & $(5)$ & (6) & (7) & ( ) \\
\hline Drogas & (1) & (2) & (3) & (4) & $(5)$ & (6) & (7) & ( ) \\
\hline Incêndio & (1) & $(2)$ & (3) & (4) & $(5)$ & (6) & (7) & ( ) \\
\hline Indústria química & (1) & (2) & (3) & (4) & $(5)$ & (6) & (7) & ( ) \\
\hline Obesidade & (1) & (2) & (3) & (4) & $(5)$ & (6) & (7) & $(\mathrm{)}$ \\
\hline Poluição do ar & (1) & (2) & (3) & (4) & $(5)$ & (6) & (7) & () \\
\hline Radiografia médica & (1) & (2) & (3) & (4) & (5) & (6) & (7) & ( ) \\
\hline Rejeito químico & (1) & (2) & (3) & (4) & $(5)$ & (6) & (7) & $($ ) \\
\hline Rejeito radioativo & (1) & (2) & (3) & (4) & $(5)$ & (6) & (7) & ( ) \\
\hline Terrorismo & (1) & (2) & (3) & (4) & $(5)$ & (6) & (7) & ( ) \\
\hline Usina nuclear & (1) & (2) & (3) & (4) & $(5)$ & (6) & (7) & $($ ) \\
\hline
\end{tabular}


24. Entre os itens citados, avalie o risco para as pessoas em geral.

\begin{tabular}{|c|c|c|c|c|c|c|c|c|}
\hline Acidente de trânsito & $\begin{array}{c}\text { Muito } \\
\text { pequena } \\
\text { (1) }\end{array}$ & $(2)$ & (3) & (4) & $(5)$ & (6) & $\begin{array}{l}\text { Muito } \\
\text { grande } \\
\text { (7) }\end{array}$ & $\begin{array}{l}\text { Não sei } \\
\text { ( ) }\end{array}$ \\
\hline Acidente doméstico & (1) & $(2)$ & (3) & (4) & (5) & (6) & (7) & ( ) \\
\hline Alcool & (1) & $(2)$ & (3) & (4) & $(5)$ & (6) & (7) & ( ) \\
\hline Aquecimento global & (1) & $(2)$ & (3) & (4) & $(5)$ & (6) & (7) & ( ) \\
\hline Alimento geneticamente modificado & (1) & (2) & (3) & (4) & $(5)$ & (6) & (7) & () \\
\hline Barulho & $(1)$ & (2) & (3) & (4) & $(5)$ & (6) & (7) & () \\
\hline Catástrofe natural & (1) & (2) & (3) & (4) & $(5)$ & (6) & (7) & () \\
\hline Cigarro & (1) & (2) & (3) & (4) & (5) & (6) & (7) & () \\
\hline Contaminação do solo & (1) & (2) & (3) & (4) & (5) & (6) & (7) & ( ) \\
\hline Dieta inapropriada & (1) & (2) & (3) & (4) & $(5)$ & (6) & (7) & ( ) \\
\hline Drogas & (1) & (2) & (3) & (4) & (5) & (6) & (7) & ( ) \\
\hline Incêndio & (1) & (2) & (3) & (4) & $(5)$ & (6) & (7) & ( ) \\
\hline Indústria química & (1) & (2) & (3) & (4) & (5) & (6) & (7) & ( ) \\
\hline Obesidade & (1) & (2) & (3) & (4) & $(5)$ & (6) & (7) & ( ) \\
\hline Poluição do ar & (1) & (2) & (3) & (4) & $(5)$ & (6) & (7) & ( ) \\
\hline Radiografia médica & (1) & (2) & (3) & (4) & $(5)$ & (6) & (7) & () \\
\hline Rejeito químico & (1) & (2) & (3) & (4) & (5) & (6) & (7) & ( ) \\
\hline Rejeito radioativo & (1) & (2) & (3) & (4) & (5) & (6) & (7) & ( ) \\
\hline Terrorismo & (1) & (2) & (3) & (4) & (5) & (6) & (7) & () \\
\hline Usina nuclear & (1) & (2) & (3) & (4) & (5) & (6) & (7) & ( ) \\
\hline
\end{tabular}

25. Julgue rápida e espontaneamente o que você sente em relação aos alimentos geneticamente modificados.

Grau muito

pequeno

Culpa

Desprezo

Medo

Otimismo

Pessimismo

Preocupação

Raiva

Satisfação

Vergonha
(1)

(1)

(1)

(1)

(1)

(1)

(1)

(1)

(1)
(2)

(3)

(4)

(5)

(4)

(5)

(6)

(6)

(5)

(6)

(5)

(6)

(5)

(6)

(5)

(6)

(5)

(6)

(5)

(6)

(5)
Grau muito elevado

(7)

(7)

(7)

(7)

(7)

(7)

(7)

(7)

(7) 
26. Julgue rápida e espontaneamente o que você sente em relação aos terrorismo. Grau muito pequeno

$\begin{array}{llllllll}\text { Culpa } & (1) & (2) & (3) & (4) & (5) & (6) & \text { (7) } \\ \text { Desprezo } & (1) & (2) & (3) & (4) & (5) & (6) & (7) \\ \text { Medo } & (1) & (2) & (3) & (4) & (5) & (6) & (7) \\ \text { Otimismo } & (1) & (2) & (3) & (4) & (5) & (6) & (7) \\ \text { Pessimismo } & (1) & (2) & (3) & (4) & (5) & (6) & (7) \\ \text { Preocupação } & (1) & (2) & (3) & (4) & (5) & (6) & (7) \\ \text { Raiva } & (1) & (2) & (3) & (4) & (5) & (6) & (7) \\ \text { Satisfação } & (1) & (2) & (3) & (4) & (5) & (6) & (7) \\ \text { Vergonha } & (1) & (2) & (3) & (4) & (5) & (6) & (7)\end{array}$

27. Julgue rápida e espontaneamente o que você sente em relação a um depósito de rejeitos radioativos.

\section{Grau muito} pequeno

Culpa

Desprezo

Medo

Otimismo

Pessimismo

Preocupação

Raiva

Satisfação

Vergonha
(1)

(1)

(1)

(1)

(1)

(1)

(1)

(1)

(1)
(2)

(2)

(2)

(2)

(2)

(2)

(2)

(2)

(2)
(3)

(3)

(3)

(3)

(3)

(3)

(3)

(3)

(3)

(4)

(5)

(6)

Grau muito elevado

(7)

28. Julgue rápida e espontaneamente o que você sente em relação aos rejeitos radioativos.

Grau muito pequeno

Culpa

Desprezo

Medo

Otimismo

Pessimismo

Preocupação

Raiva

Satisfação

Vergonha
(1)

(1)

(1)

(1)

(1)

(1)

(1)

(1)

(1)
(2)

(2)

(2)

(2)

(2)

(2)

(2)

(2)

(2)
(3)

(3)

(3)

(3)

(3)

(3)

(3)

(3)

(3)
(4)

(4)

(4)

(4)

(4)

(4)

(4)

(4)

(5)

(5)
(6)

(6)

(6)

(6)

(6)

(6)

(6)

(6)
(7)

(7)

(7)

(7)

(7)

(7)

(7)

(7) 
29. Julgue rápida e espontaneamente o que você sente em relação a energia solar. Grau muito pequeno

$\begin{array}{llllllll}\text { Culpa } & (1) & (2) & (3) & (4) & (5) & (6) & \text { (7) } \\ \text { Desprezo } & (1) & (2) & (3) & (4) & (5) & (6) & \text { (7) } \\ \text { Medo } & (1) & (2) & (3) & (4) & (5) & (6) & (7) \\ \text { Otimismo } & (1) & (2) & (3) & (4) & (5) & (6) & (7) \\ \text { Pessimismo } & (1) & (2) & (3) & (4) & (5) & (6) & (7) \\ \text { Preocupação } & (1) & (2) & (3) & (4) & (5) & (6) & (7) \\ \text { Raiva } & (1) & (2) & (3) & (4) & (5) & (6) & (7) \\ \text { Satisfação } & (1) & (2) & (3) & (4) & (5) & (6) & (7) \\ \text { Vergonha } & (1) & (2) & (3) & (4) & (5) & (6) & (7)\end{array}$

30. A instalação de um depósito de rejeitos radioativos em seu município deve...

Concordo

totalmente

Ser evitada, a menos que seja provado não oferecer riscos.

Ser aceita, desde que ofereça alguns benefícios.

Ser aceita, caso não haja provas de que é perigoso.

Ser aceita, mesmo que os riscos sejam mínimos.

Ser evitada, independentemente do quão seguro é a informação sobre os riscos.

Ser aceita, se provado oferecer mais benefícios que riscos.

Ser evitada, caso haja uma alternativa à sua construção a custos razoáveis

Ser evitada, até que se saiba mais sobre os riscos.

Ser evitada, a menos que os riscos sejam voluntariamente assumidos pela comunidade

Ser evitada, pois nem a ciência alcançará conhecimento absoluto dos riscos futuros associados.

Ser evitada, no caso das pessoas se preocuparem com os riscos, mesmo sem terem sido provados.

Ser evitada, a menos que forneça fortes argumentos científicos de que o risco é mínimo.
(1)

(2)

(1)

(2)

(3)

(1)

(2)

(3)

(4)

(5)

(1)

(2)

(3)

(4)

(5)

(6)

(7)

(1)

(2)

(3)

(4)

(5)

(6)

(7)

(1)

(2)

(3)

(4)

(5)

(6)

(2)

(3)

(4)

(5)

(6)

(7)

(1)

(2)

(3)

(4)

(5)

(6)

(7)

(1)

(2)

(3)

(4)

(5)

(6)

(7)

(1) (2)

(3)

(4)

(5)

(6)

(7)

(1)

(2)

(3)

(4)

(5)

(6)

(7)

(1) (2)

(3)

(4)

(5)

(6)

(7) 
31. Sexo:

( ) Feminino

( ) Masculino

32. Idade:

( ) Menor de 16 anos

( ) $16-24$

( ) $25-29$

( ) $30-39$

( ) $40-49$

( ) 50 ou mais

33. Educação (o maior nível de estudo):

( ) Ensino Fundamental incompleto ou completo

( ) Ensino Médio incompleto ou completo

( ) Ensino Superior incompleto ou completo

( ) Pós-graduação

34. Renda (em salários mínimos):
( ) Até 1
( ) De 1 a 2
( ) De 2 a 5
( ) De 5 a 10
( ) Mais que 10 


\section{REFERÊNCIAS BIBLIOGRÁFICAS}

ANEEL - AGÊNCIA NACIONAL DE ENERGIA ELÉTRICA. Atlas de energia elétrica no Brasil. Brasília, 2008.

BECK, U. World Risk Society. Polity Press, Cambridge, 1999.

CNEN - COMISSÃO NACIONAL DE ENERGIA NUCLEAR. Glossário de segurança nuclear. Rio de Janeiro, 2011.

DROTTZ-SJÖBERG, B.; SJÖBERG, L. Risk perception and worries after the Chernobyl accident. Journal of Environmental Psychology, v. 10, p. 135-149. 1990.

ELETRONUCleAR. Panorama da Energia Nuclear no Mundo. Rio de Janeiro, 2010.

FISCHHOFF,B.; SLOVIC, P.; LICHTENSTEIN, S.; READ, S.; COMBS, B. How safe is safe enough? A psychometric study of attitudes towards technological risks and benefits. Policy Sciences, v. 9, p. 127-152. 1978.

GARRICK, B. J. The analysis, communication and perception of risk. New York, 1991.

GUIMARÃES, L.S. Síntese de doutrina de segurança para projeto e operação de submarinos nucleares. 1999. Tese (Doutorado). Escola Politécnica da Universidade de São Paulo. São Paulo.

HAMMERSCHMIDT, D. O risco na sociedade contemporânea e o princípio da precaução no direito ambiental. Revista Sequência, n. 45, p. 97-122. 2002.

HAYES, B.E. Medindo a satisfação do cliente. Qualitymark Editora. Rio de Janeiro, 1996.

HILL, M.M.; HILL. A. Investigação por questionário. Edições Sílabo. Lisboa, Ed 2, 2009.

IAEA - INTERNATIONAL ATOMIC ENERGY AGENCY. Public Attitudes toward Nuclear Power. IAEA Bulletin. v.18, n. 5/6, p. 53-59. 1976.

IAEA - INTERNATIONAL ATOMIC ENERGY AGENCY. IAEA Safety glossary. Terminology used in nuclear safety and radiation protection. Vienna, 2003.

IAEA - INTERNATIONAL ATOMIC ENERGY AGENCY. IAEA Classification of radioactive waste. (GSG-1). Vienna, 2009. 
IEA - INTERNATIONAL ENERGY AGENCY. Key World Energy Statistics. Paris, 2010.

IRSN - INSTITUT DE RADIOPROTECTION ET DE SÛRETÉ NUCLÉAIRE Baromètre IRSN: La perception des risques et de la sécurité par les Français, Rapport IRSN-DSDRE no 16. France: 2009.

IPEN - INSTITUTO DE PESQUISAS ENERGÉTICAS E NUCLEARES. Noções básicas de proteção radiológica. São Paulo, 2002.

KUNREUTHER, H.; SLOVIC, P. Coping with stigma: challenges and opportunities. Risk: Health, Safety \& Environment, v.10, p. 269-280. 1999.

MME - MINISTÉRIO DE MINAS E ENERGIA. Balanço Energético Nacional. Rio de Janeiro, 2009.

NSC - NATIONAL SAFETY COUNCIL. Regulating risk: the science and politics of risk. Washington, 1993.

PETTERSON, J. Perception vs. reality of radiological impact: the Goiania model. Nuclear News, 1988.

RENN, O. Concepts of risk: an interdisciplinary review. GAIA, v. 17 , n. 1, p. 50-56. 2008.

ROCCA, F.F.D. A percepção de risco como subsídio para os processos de gerenciamento ambiental. 2002. Tese (Doutorado). Instituto de Pesquisas Energéticas e Nucleares. São Paulo.

ROHRMANN, B. Risk perception, risk attitude, risk communication, risk management: a comeptual appraisal. In: $15^{\text {th }}$ TIEMS Annual Conference 2008, The International Emergency Management Society. Praha 2008

SJÖBERG, L. Explaining risk perception: an empirical and qualitative evaluation of cultural theory. Rhikizon: Risk Research Report, n. 22. 1995. Centre for risk research, University of Stockholm, Sweden.

SJÖBERG, L. Understanding the process and consequences of risk perception. In A. Moslet and R.A. Bari (Ed.) $4^{\text {th }}$ Conference on probabilistic safety assessment and management 3, p. 1979-1984. New York city: Springer. 1998.

SJÖBERG, L. Factors in risk perception. Risk Analysis, v. 20, n. 1, p. 1-11. 2000a.

SJÖBERG, L. Specifying factors in radiation risk perception. Scandinavian Journal of Psychology, v. 41, p. 169-174. 2000b. 
SJÖBERG, L. The methodology of risk perception research. Quality \& Quantity, v. 34, p. 407-418. 2000d.

SJÖBERG,L. Limits of knowledge and the limited importance of trust. Risk Analysis v. 21, n. 1, p. 189-198. 2001.

SJÖBERG,L. Attitudes towards technology and risk: going beyond what is immediately given. Policy Sciences v. 35, p. 379-400. 2002.

SJÖBERG, L. Risk Perception, Emotion, and Policy: The Case of Nuclear Technology. European Review. v. 11, n. 1, p. 109-128. 2003.

SJÖBERG, L. The different dynamics of personal and general risk. Risk Management, v. 5, p. 19-34. 2003a.

SJÖBERG, L. Asking questions about risk and worry: dilemmas of the pollsters. Journal of Risk Research, v. 7, n. 7, p. 671-674. 2004a.

SJÖBERG, L. Explaining individual risk perception: the case of nuclear waste. Risk Management, v. 6, n. 1, p. 51-64. 2004b.

SJÖBERG, L.; MOEN, B-E; RUNDMO, T. Explaining individual risk perception. An evaluation of the psychometric paradign in risk perception research. Rotunde publikasjoner, n. 84. 2004.

SJÖBERG, L. Nuclear waste risk perceptions and attitudes in siting a final repository for spent nuclear fuel. In K. Andersson (Ed.), VALDOR 2006. Proceedings (pp. 452-460). Stockholm.

SJÖBERG, L. Emotions and risk perception. Risk Management. v.9, p. 223-237. 2007.

SJÖBERG, L. Antagonism, trust and perceived risk. Risk Management, v. 10, p. 32-55. 2008.

SJÖBERG, L.; DROTTZ-SJÖBERG, B-M. Attitudes towards nuclear waste and siting policy: experts and the public. In: Lattefer, A.P. (ed). Nuclear waste research: siting, technology and treatment. N.Y., Nova Science Publishers, p. 47-74. 2008.

SJÖBERG, L.; HERBER, M.W. Too much trust in (social) trust? The importance of epistemic concerns and perceived antagonism. Int. J. Global Environmental Issues, v. 8, n. 1/2, p. 30-44. 2008.

SJÖBERG, L. Dynamics of risk perception (Seminar). In: Seminário Internacional: Risco, Saúde e Meio Ambiente, September 21-22 (2009) São Paulo. 
SJÖBERG, L. Precautionary attitudes and the acceptance of a local nuclear waste repository. Safety Science . v. 47, p. 542-546. 2009a.

SJÖBERG, L.; DROTTZ-SJÖBERG, B-M. Public Risk perception of nuclear waste. Int. Journal Risk Assessment and Management, v. 11, n. 3/4, p. 264-296. 2009.

SLOVIC, P.; FISCHHOLF, B.; LICHTENSTEIN, S. Facts and fears: understanding perceived risk. In: Slovic, P. (ed). The Perception of Risk. London, Earthscan, p. 137-153. 2001.

SLOVIC, P. Perception of risk from radiation. Radiation Protection Dosimetry, v.68(3/4), p. 165-180. 1996.

SLOVIC, P. Perception of risk. Science, v.236(4799), p. 280-285. 1987.

SCHMIDT, M. Investigating risk perception: a short introduction (2004). PhD Thesis, Vienna, Austria.

STARR, C. Social benefit versus technological risk. Science, v.165, p. 1232-1238. 1969.

SKB - SVENSK KÄRNBRÄNSLEHANTERING AB - SKB Rapport R-06-97: Opinion och attityder till förvaring av använt kärnbränsle, SKB Rapport R-0697.Stockholm, Sweden: 2006.

TOUZET, R.E.; BARÓN, J.H.; CASPANI, C.; REMEDI, J.O. Risk Perception and Benefits Perception (Survey Results and discussion). In: $10^{\text {th }}$ International Congress of the International Radiation Protection Association, Mayo 14-19 (2000) Hiroshima. 
